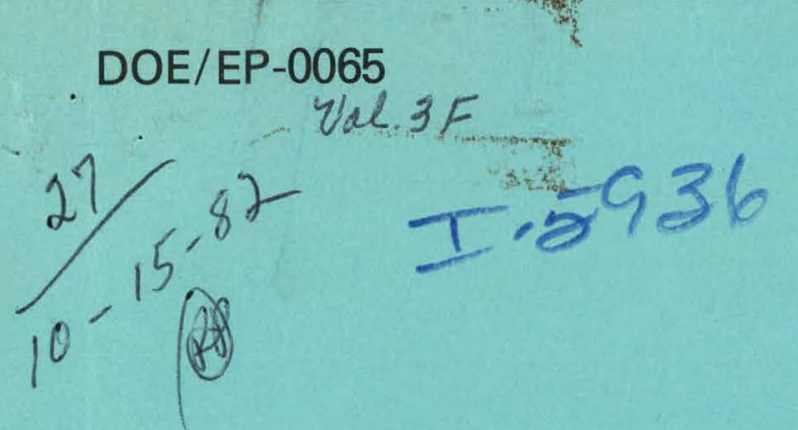

(1)

\title{
Environmental Compliance Guide
}

\section{Guidance Manual For Department of Energy Compliance With The Clean Air Act: Nonattainment Areas September 1982}

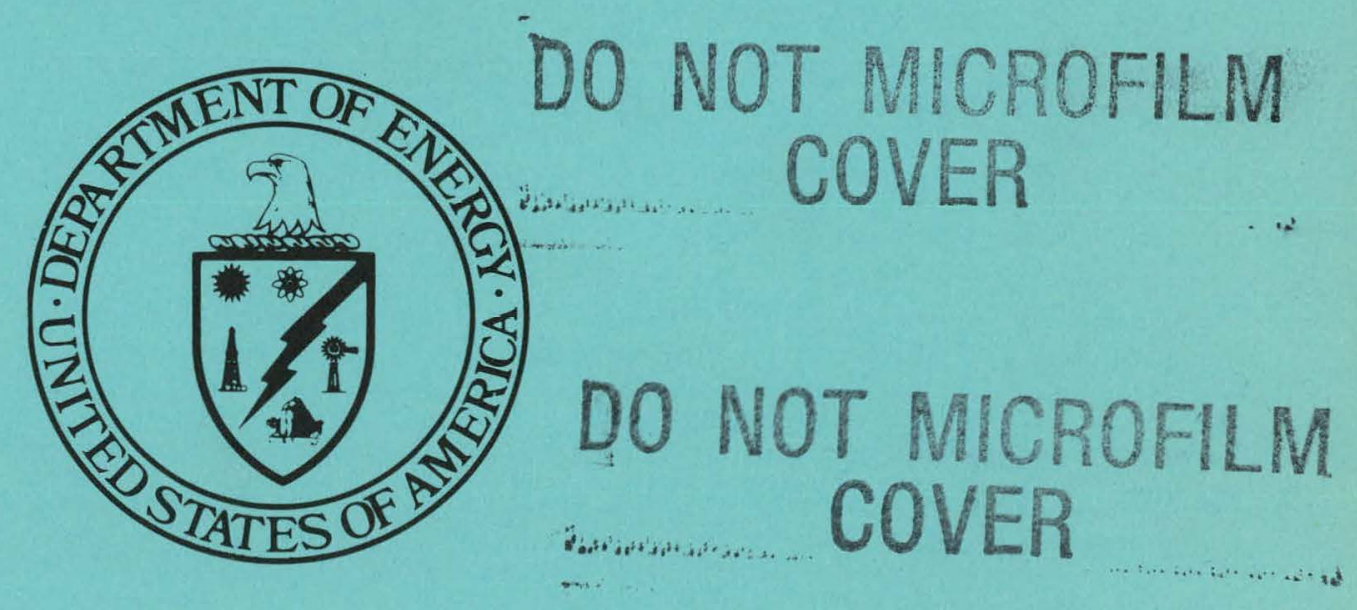

\section{U.S. Department of Energy}

Assistant Secretary for Environmental Protection, Safety, and Emergency Preparedness

Deputy Assistant Secretary for Environment, Safety and Health

Office of Environmental Compliance 


\section{DISCLAIMER}

This report was prepared as an account of work sponsored by an agency of the United States Government. Neither the United States Government nor any agency Thereof, nor any of their employees, makes any warranty, express or implied, or assumes any legal liability or responsibility for the accuracy, completeness, or usefulness of any information, apparatus, product, or process disclosed, or represents that its use would not infringe privately owned rights. Reference herein to any specific commercial product, process, or service by trade name, trademark, manufacturer, or otherwise does not necessarily constitute or imply its endorsement, recommendation, or favoring by the United States Government or any agency thereof. The views and opinions of authors expressed herein do not necessarily state or reflect those of the United States Government or any agency thereof. 


\section{DISCLAIMER}

Portions of this document may be illegible in electronic image products. Images are produced from the best available original document. 
This report has been reproduced directly from the best available copy.

Available from the National Technical Information Service, U. S. Department of Commerce, Springfield, Virginia 22161.

$$
\begin{array}{r}
\text { Price: Printed Copy A04 } \\
\text { Microfiche A01 }
\end{array}
$$

Codes are used for pricing all publications. The code is determined by the number of pages in the publication. Information pertaining to the pricing codes can be found in the current issues of the following publications, which are generally available in most libraries: Energy Research Abstracts, (ERA); Government Reports Announcements and Index (GRA and I); Scientific and Technical Abstract Reports (STAR); and publication, NTIS-PR-360 available from (NTIS) at the above address. 


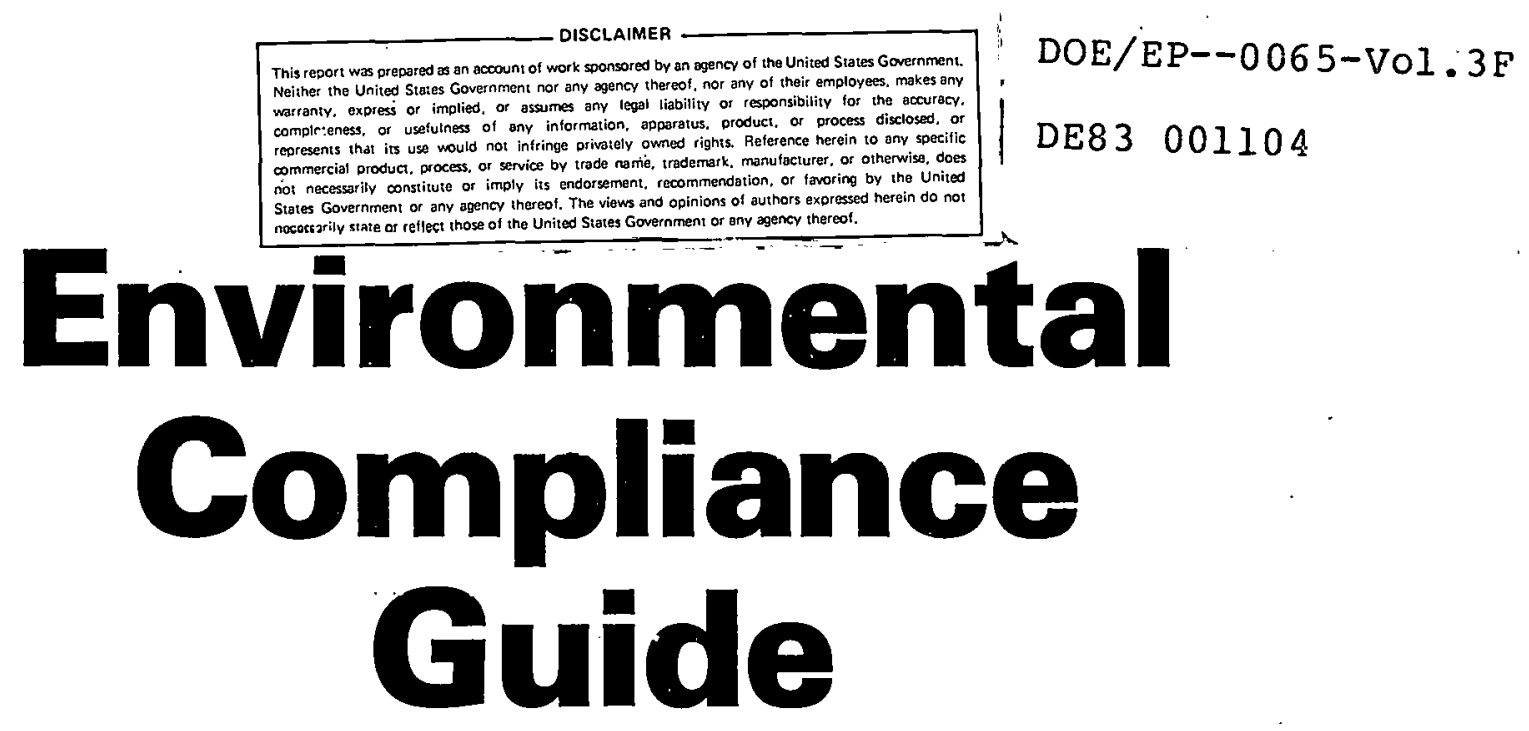

Guidance Manual For Department of Energy Compliance With The Clean Air Act:
Nonăttainment Areas
September 1982

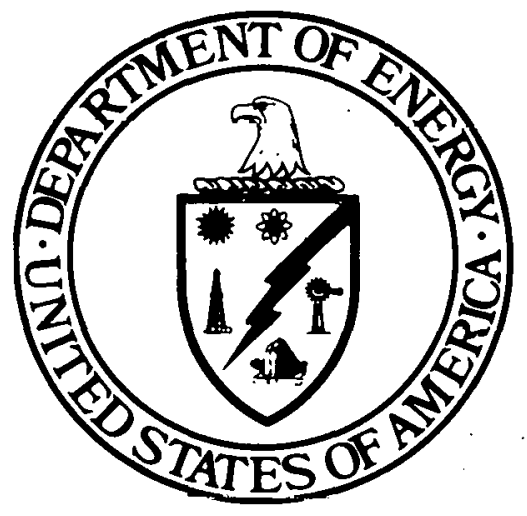

\section{U.S. Department of Energy}

Assistant Secretary for Environmental Protection, Safety, and Emergency Preparedness

Deputy Assistant Secretary for Environment, Safety and Health Office of Environmental Compliance 
THIS PAGE

WAS INTENTIONALLY

LEFT BLANK 
This guidance manual has been prepared to assist Department of Energy personnel in developing information and performing analyses commensurate with federal requirements for the permitting of stationary air pollution sources in nonattainment areas, pursuant to the provisions of the Clean Air Act (CAA) (Pub. L. 91-604), as amended (Pub. L. 95-95). The manual does not add new requirements nor does it alter existing requirements under the CAA permitting program and associated regulations. Rather, the manual is intended to be advisory and to present guidance and information which should assist DOE compliance efforts. Early contact and consultation with appropriate regulatory agencies is essential for adequate compliance with the cAA. Supplements to this guidance manual will be issued if regulations are significantly modified or if the CAA is amended. 
THIS PAGE

WAS INTENTIONALLY

LEFT BLANK 
This document was prepared for the U.S. Department of Energy, Office of the Assistant Secretary for Environmental Protection, Safety, and Emergency Preparedness, Deputy Assistant Secretary for Environment, Safety and Health, office of Environmental Compliance by Donald B. Hunsaker, Jr., of the Energy Division, Oak Ridge National Laboratory, Oak Ridge, Tennessee (operated by Union Carbide Corporation under contract W-7405-eng-26 with the Department of Energy). Personnel from various state and local airpoliution control agencies and regional offices of the U.S. Environmental Protection Agency were helpful in providing information on the permitting process and available quidelines. Francis $C$. Kornegay of the Energy Division and Robert M. Reed of the Environmental Sciences Division, Oak Ridge National Laboratory, reviewed the manuscript. Robert $M$. Reed served as project manager. 
THIS PAGE

\section{WAS INTENTIONALLY LEFT BLANK}


The purpose of this manual is to identify information requirements associated with air quality permit applications in areas for which ambient pollutant levels currently exceed the national ambient air quality standards (nonattainment areas). The manual is to be used by project managers at the U.S. Department of Energy (DOE), in conjunction with the DOE Environmental Compliance Guide, to provide preliminary estimates of information required to obtain air quality permits for DOE projects. An analysis. of nonattainment area permitting found that permitting of all sources in such areas is done on the state or local levels; the Environmental Protection Agency does not grant permits in nonattainment areas. As a result, Federal information requirements for permitting in nonattainment areas are somewhat vague. To provide a more realistic picture of nonattainment area permitting, selected state and local regulations were surveyed, and were found to contain more detail on the information required for permit approval. The most potentially demanding information requirements associated with nonattainment area permitting are the determination of Lowest Achievable Emission Rate, the negotiation of external emission offsets, and the consideration of the environmental impacts of. project alternatives in ozone and carbon monoxide nonattainment areas. In any state, a few information requirements for nonattainment area permitting are likely to overlap with information requirements of other permitting processes, such as those in the prevention of Significant Deterioration procedure. These requirements are emissions data and air quality modeling and its associated input data requirements (meteorology, topography, etc.). 
THIS PAGE

WAS INTENTIONALLY

LEFT BLANK 


\section{Glossary of Acronyms}

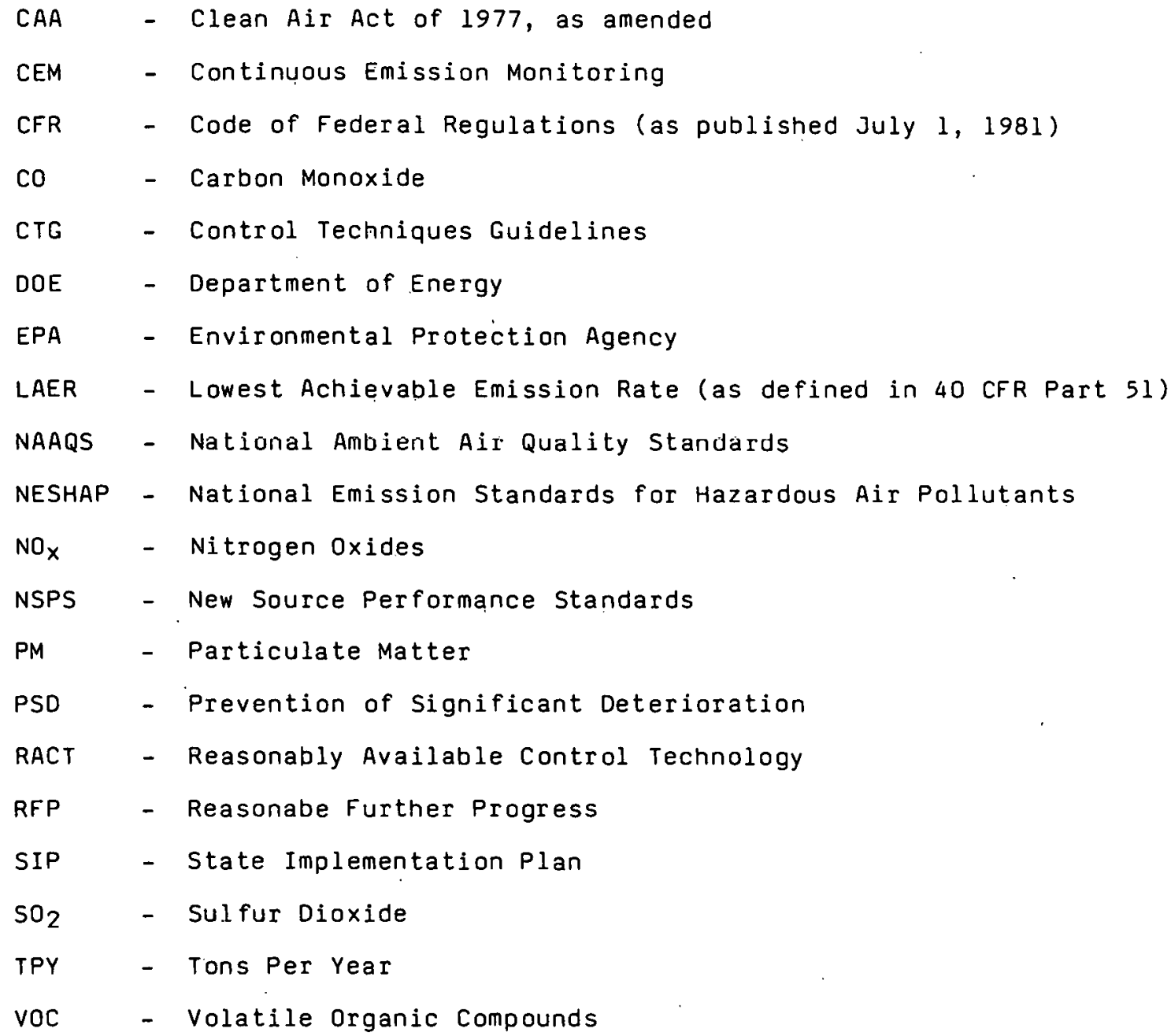


THIS PAGE

\section{WAS INTENTIONALLY LEFT BLANK}


PREFACE

PAGE

ACKNOWLEDGMENTS

ABSTRACT

GLOSSARY OF ACRONYMS

LIST OF FIGURES

LIST OF TABLES

1. INTRODUCTION

2. BACKGROUND

2.1 Nonattainment Area Regulations

2.2 New Source Performance Standards

2.3 National Emission Standards for Hazardous Air Pollutants . . . . . .

3. DOE COMPLIANCE

3.1 Determination of Attainment Status

3.2 Preliminary Estimate of Emissions

3.3 Applicability of Regulations

3.3.1 Preconetruction Roviow.

3.3.2 New Source Performance Standards (NSPS)

3.3.3 National Emission Standards for Hazardous Air Pollutants.

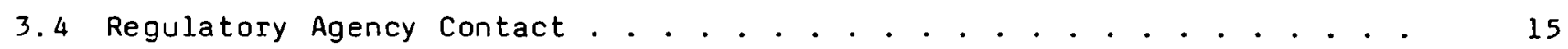

3.5 Identification of Environmental Information Requirements . . . . . . 15

3.5.1 Preconstruction Review . . . . . . . . . . . . . . . 16

3.5.2 New Source Performance Standards. . . . . . . . . . . . . . . . 24

3.5.3 National Emission Standards for Hazardous Air Pollutants . . . . 27

3.6 Permit Applications... . . . . . . . . . . . . . . . . 28

3.7 Exemptions from Regulatory Review.................. . 28

3.8 Consideration of Alternatives... . . . . . . . . . . . . . 33

3.9 Post-Permitting Requirements ................... . . . 33

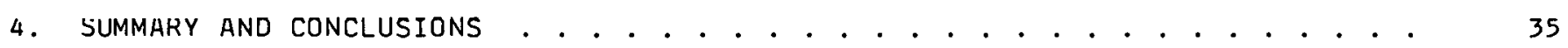

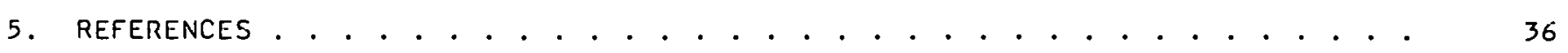

APPENDIX A Maps of Areas in the U.S. Recently Designated as Nonattainment for the Primary National Ainiliul Ail Qualily Slandards.........

APPENDIX $B$ List of States with Authority to Implement New Source Performance

APPENDIX $C$ List of States with Authority to Implement National. Emission Standards for Hazardous Air Pollutants...............

APPENDIX D List of State Air Pollution Control Agencies.............. 


\section{THIS PAGE \\ WAS INTENTIONALLY \\ LEFT BLANK}


TABLE

PAGE

1 National ambient air quality standards...................

2 New source performance standards for energy projects . . . . . . . . . . .

National emission standards for hazardous air pollutants . . . . . . . . .

4 Air pollutants regulated under the Clean Air Act . . . . . . . . . . . . .

Example major source and major modification thresholds enforced by state and local air pollution control agencies... . . . . . . . . . . . . .

Example emission offset ratios required by state and local air pollution control agencies.............................

8 Monitoring requirements associated with new source performance standards for energy related projects . . . . . . . . . . . . . . . . . . . . . . .

9 Example information requirements associated with air quality permitting procedures in states and local air pollution control agencies

\section{List of Figures}

\section{F IGURE}

1 Basic steps for obtaining air permits in non-attainment areas . . . . .

2 Emissions banking form used by the Jefferson County (Kentucky) Air Pollution Control District . . . . . . . . . . . . . . . . . . . . . . .

3 Sample permit application for a fuel-burning facility . . . . . . . . . .

4 Continuation of permit system . . . . . . . . . . . . . . . . . . . . . . 


\section{Introduction}

State and local air pollution control agencies have the responsibility for issuing or denying permits to construct and operate stationary sources of air pollution in areas of the country that are violating ambient air quality standards (nonattainment areas). These permitting programs were developed in response to Part $D$ of Title $I$ of the Clean Air Act (CAA) and in response to regulations (40 CFR 51.18J) promulgated by the U.S. Environmental Protection Agency (EPA). The EPA has the responsiblity for establishing National Ambient Air Quality Standards (NAAQS) that are used to define nonattainment areas, for formally designating the nonattainment areas, and for publishing technical guidance that is used to meet the information requirements of the state and local permitting processes.

This manual provides general guidance on complying with Part D, Title I of the CAA. It is one of a series of documents developed by the Environmental Compliance Division of the U.S. Department of Energy (DOE) to provide DOE project managers with guidance on obtaining information for environmental permits. The manual augments and should be used in conjunction with the DOE Environmental Compliance Guide, which outlines the procedures that must be followed to secure approved environmental permits for DOE projects (DOE 198la). The flowcharts in the Guide numbered Flow III-l (a), (b), and (c) outline the steps in the permitting procedure for DOE compliance with the CAA. Flowchart III-l(a) in the Environmental Compliance Guide is concerned with information needed to prepare a permit application and thus will be referred to more in this manual than the other two flowcharts (which are concerned with agency review of the permit applications). A companion manual discusses the information requirements for permitting in attainment areas (DOE 1982). Note that attainment status is designated on a pollutant specific basis, and that both guidance manuals could be required for a given DOE project. These manuals and the compliance guide will help implement DoE order 5480.1A, which is concerned with environmental protection, safety, and health protection programs for DOE operations (DOE 1981b).

The second section of this manual provides background information on the laws and regulations affecting permitting in nonattainment areas. Information requirements that DOE must meet to comply with the provisions of the CAA applicable to projects locating in nonattainment areas are discussed in sect. 3. Section 4 summarizes major findings and presents some conclusions.

\section{Background}

The Clean Air Act (Pub. L. 91-604) as amended (Pub. L. 95-95) is the principal body of federal air pollution legislation in the United States. It is based on the premise that reductions in pollutant emissions will result in ambient pollutant levels that will not endanger public health and welfare. The primary means for achieving emission reductions is through regulations implemented and enforced via a permit system.

Two basic types of emission limitations are required by the CAA (hereafter referred to as the Act): those that depend on existing pollutant levels of a given area and those that depend on the type of source. Existing pollutant levels of a given area, when compared with ambient standards established by EPA, determine the attainment status of an area. An area is classified as attainment (pollutant levels are lower than standards) or nonattainment (pollutant levels are greater than the standards). This manual is concerned with the latter situation. National emission standards are established for specified types of industries in New Source Performance Standards (NSPS) and National Emission Standards for Hazardous Air Pollutants (NESHAP). Compliance with the nonattainment area regulations, the NSPS, and the NESHAP is required to obtain approved permits for new sources in nonattaiment areas. Each of these will therefore be discussed in this manual.

The CAA directs EPA to develop National Ambient Air Quality Standards (NAAQS) that represent the maximum levels of air pollutants that can legally exist in the air to which the general public has access (ambient air). The NAAQS, which are found in 40 CFR Part 50, are summarized in Table 1. Pollutants for which NAAQS are established are termed criteria pollutants. Primary NAAQS protect public health and secondary NAAQS protect public welfare (e.g., crop damage, materials damage, visibility impairment, 
Table 1. National Ambient Air Quality Standards

\begin{tabular}{|c|c|c|}
\hline Pollutant & $\begin{array}{c}\text { Primary Standard } \\
\left(\mu \mathrm{g} / \mathrm{m}^{3}\right)\end{array}$ & $\begin{array}{c}\text { Second ary standard } \\
\left(\mu \mathrm{g} / \mathrm{m}^{3}\right)\end{array}$ \\
\hline \multicolumn{3}{|l|}{ Sulfur dioxide } \\
\hline $\begin{array}{l}\text { Annual arithmetic } \\
24-\text { Houra } \\
3 \text {-Houra }\end{array}$ & $\begin{array}{r}80 \\
365 \\
\text { None }\end{array}$ & $\begin{array}{l}\text { None } \\
\text { None } \\
1,300\end{array}$ \\
\hline \multicolumn{3}{|l|}{ Particulate matter } \\
\hline $\begin{array}{l}\text { Annual geometric } \\
24 \text {-Hour }\end{array}$ & $\begin{array}{r}75 \\
260\end{array}$ & $\begin{array}{l}60^{\mathrm{b}} \\
150^{\circ}\end{array}$ \\
\hline \multicolumn{3}{|l|}{ Carbon monoxide } \\
\hline $\begin{array}{l}8-\text { Houra } \\
1 \text {-Houra }\end{array}$ & $\begin{array}{l}10,000 \\
40,000\end{array}$ & $\begin{array}{l}10,000 \\
40,000\end{array}$ \\
\hline \multicolumn{3}{|l|}{ Ozone } \\
\hline 1 -Hourc & 235 & 235 \\
\hline \multicolumn{3}{|l|}{ Nitrogen dioxide } \\
\hline Annual arithmetic & 100 & 100 \\
\hline \multicolumn{3}{|l|}{ Lead } \\
\hline Calendar Uuarter & 1.5 & 1.5 \\
\hline \multicolumn{3}{|l|}{ Hydrocarbons } \\
\hline 3 -Hour $\left(6 \text { to } 9 \mathrm{a} \cdot \mathrm{m}_{.}\right)^{\mathrm{d}}$ & 160 & 160 \\
\hline
\end{tabular}

anot to be exceeded more than once per year.

bThe secondary standard of $60 \mu \mathrm{g} / \mathrm{m}^{3}$ is a guide to be used in assessing implementaton plans to achieve the 24-hour standard.

cstandard attained when the expected number of days per calendar year with maximum hourly average concentrations above $235 \mathrm{\mu g} / \mathrm{m}^{3}$ and 0.12 ppm is equal to one or less.

dHydrocarbon 3 -hour standard used only as a guide to tevelop plans for aclituvillg ozonc standard.

Source: 40 CFR Part 50. 
etc.). Only for the pollutants particulate matter and sulfur dioxide are the secondary standards different from the primary. States may establish their own ambient standards, as long as they are at least as stringent as the federal NAAQS. The state ambient standards are typically used as part of state and local permitting programs.

\subsection{Nonattainment Area Regulations}

The CAA (Section 107) directs states to identify, and EPA to formally designate, those areas in which the NAAQS are being violated (nonattainment areas). These nonattainment areas, which are listed in 40 CFR 81.300 et seq., can be as large, as an entire state or as small as a portion of a city or town. The list of attainment status in 40 CFR 81.300 et seq. is revised periodically as new data become available. Appendix A presents maps of recently designated nonattainment areas. It is important to note that attainment status designation is pollutant specific and is also made with respect to primary and secondary standards. As an example, a given area may have nonattainment status for the primary sulfur dioxide standard and attainment status for the ozone standard.

Section 110 of the CAA designates the primary responsibility of air pollution control at its source to state and local governments. States are directed to prepare State Implementation Plans (SIPS) for controlling air pollution in their jurisdictions. The immediate goal of the SIPS is attainment of the primary NAAQS; secondary NAAQS are to be attained within a reasonable time (no statutory deadline was established). In nonattainment areas, states must demonstrate reasonable further progress (RFP) towards attaining the NAAQS. Once a nonattainment area has been formally designated by the EPA under Section 107 of the CAA, the state must then either develop, as part of the SIP, a nonattainment area permitting program pursuant to $40 \mathrm{CFR} 51.18 \mathrm{~J}$, or else face a construction ban imposed by EPA for the particular nonattainment area in question (46 FR 41496). State ambient standards may not be used as goals for the SIPs; all official attainment designations are made with respect to the NAAQS. Approval authority over tine SIPs was given to EPA, which was also given authority to impose regulations if a state fails to develop a SIP Or if a submitted SIP is not adequate. The deadline for submitting SIPS to EPA was July 1, 1979. To date the nonattainment area portions of most SIPs submitted to EPA have been approved; construction bans are being enforced in portions of at least four states.

The requirements for emission regulations and permitting programs in sIPs are contained in Sect. 120 of the 1970 Act. The basic problem in nonattainment areas at the time the 1970 Act was drafted was developing mechanisms to allow industrial growth in nonattainment areas without exacerbating an existing air quality problem. A strict interpretation of the 1970 Act essentially forbade all new source construction in nonattainment areas. On December 21,1976 , EPA issued its Emission offset Interpretive Ruling (4l FR 55525) that specified how nonattainment areas could allow industrial growth while still making progress toward standard attainment. When Congress amended the CAA in 1977, they added the Interpretive Ruling to Sect. 129, thus creating Part D of Title I of the Act. On January 16, 1979, EPA revised the Interpretive Rul1ng (44 FR 3274 ) to make minor changes in definitions and requirements. The 1979 Ruling applied to all applications. for construction permits filed before July 1 , 1979 , the date when all states with approved SIPs assumed responsiblity for review and approval of new sources in nonattainment areas. States must either develop a preconstruction review program for nonattainment areas (under 40 CFR $51.18 \mathrm{~J}$ ), or else face a construction ban under which no new sources would be allowed.

State and local regulations and permitting programs based on 40 CFR $51.18 \mathrm{~J}$ are not the only emission limitations facing a new source in nonattainment areas. Two additional types of regulations, which are applicable in all areas of the country (attainment, nonattainment, or unclassified), could place additional limitations on a new source, depending upon the source type.

\subsection{New Source Performance Standards}

New Source Performance standards (NSPS) are maximum allowable emission limitations on 28 categories of industrial sources. The legislative mandate for NSPS is found in Sect. Ill of the CAA, and the standards themselves, which are proinulgaled by EPA, are found in 40 CFR Part 60 . Table 2 lists the NSPS for energy-related industries with which DOE is likely to become involved. 
Table 2. New Source Performance Standards for energy projects

\begin{tabular}{|c|c|c|c|}
\hline Source categorya & Affected facilities & Pollutant & Emission limitb \\
\hline $\begin{array}{l}\text { Subpart } D \text { : } \\
\text { Fossil-fuel-fired } \\
\text { steam generators }\end{array}$ & $\begin{array}{l}\text { Fossil fuel and wood-fired } \\
\text { steam generating units capable } \\
\text { of firing fuel at a heat input } \\
\text { rate of more than } 73 \mathrm{MW} \\
\text { ?250 MMBtu/hr) }\end{array}$ & $\begin{array}{l}\text { TSP } \\
\text { Opacity } \\
\mathrm{SO}_{2} \\
\text { liquid fuel or liquid + wood } \\
\text { solid fuel or solid + wood } \\
\mathrm{NO} \\
\text { gas or gas + wood } \\
\text { liquid or liquid }+ \text { wood } \\
\text { solid om solid }+ \text { woodd }\end{array}$ & $\begin{array}{l}43 \mathrm{ng} / \mathrm{J} \text { heat input }(0.1 \mathrm{lb} / \mathrm{MMBtu}) \\
6 \mathrm{~min} \text { average not greater than } 20 \% \mathrm{c} \\
340 \mathrm{ng} / \mathrm{J}(0.8 \mathrm{lb} / \mathrm{MMBtu}) \\
520 \mathrm{ng} / \mathrm{J}(1.2 \mathrm{~b} / \mathrm{MMBtu}) \\
86 \mathrm{ng} / \mathrm{J}(0.21 \mathrm{~b} / \mathrm{MMBtu}) \\
130 \mathrm{ng} / \mathrm{J}(0.3 \mathrm{lb} / \text { MMBtu}) \\
300 \mathrm{ng} / \mathrm{J}(0.7 \mathrm{lb} / \text { MMBtu })\end{array}$ \\
\hline $\begin{array}{l}\text { Subpart Da: Electric } \\
\text { utility steam } \\
\text { generating units }\end{array}$ & 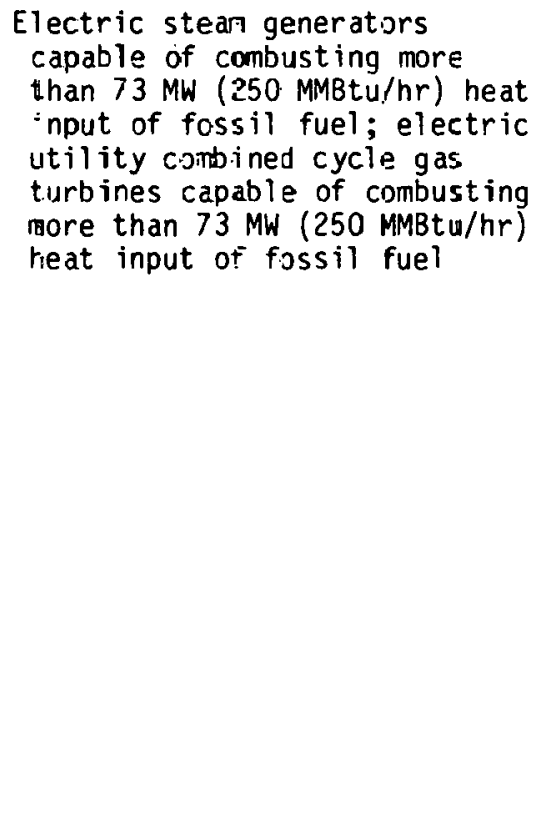 & $\begin{array}{l}\text { TSP } \\
\text { gaseaus fuel } \\
\text { liquid fuel } \\
\text { solid fuel } \\
\text { Opacity } \\
\mathrm{SO}_{2} \\
\text { solid or solid-derived fuele }\end{array}$ & 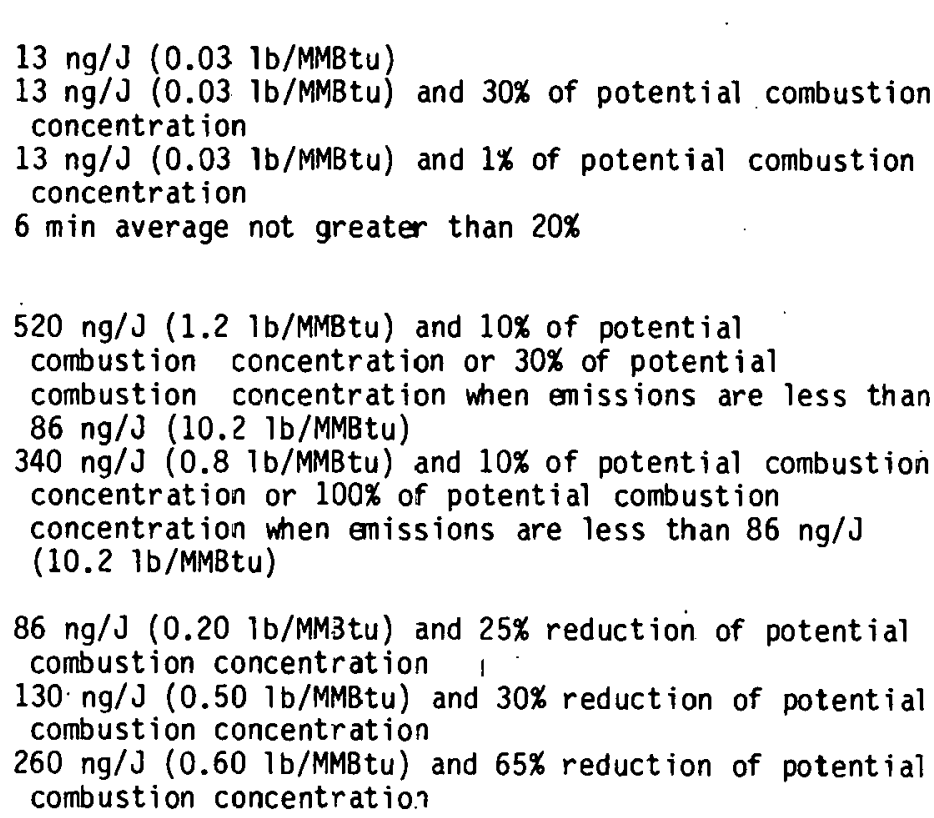 \\
\hline
\end{tabular}


Table 2. New Source Performance Standards for energy projects

(continued)

\begin{tabular}{|c|c|c|c|}
\hline Source categorya & Affected facilities & Pollutant & Emission limitb \\
\hline $\begin{array}{l}\text { Subpart E: } \\
\text { Incinerators }\end{array}$ & $\begin{array}{l}\text { Incinerators with charging } \\
\text { rates in excess of } 45 \mathrm{MT} / \text { day } \\
\text { (50 tons/day) }\end{array}$ & TSP & $0.18 \mathrm{~g} / \mathrm{dscm}(0.08 \mathrm{gr} / \mathrm{dscf})$ corrected to $12 \% \mathrm{co}_{2}$. \\
\hline \multirow[t]{4}{*}{$\begin{array}{l}\text { Subpart J: } \\
\text { Petroleum } \\
\text { refiners }\end{array}$} & $\begin{array}{l}\text { Fluid catalytic cracking unit } \\
\text { catalyst regenerators; fuel gas } \\
\text { combustion devices; claus sulfur } \\
\text { recovery plants with capacity } \\
\text { exceeding } 20 \text { long tons/day }\end{array}$ & $\begin{array}{l}\text { TSP } \\
\text { catalyst regenerator } \\
\text { fuel combustion }\end{array}$ & $\begin{array}{l}1.0 \mathrm{~kg} / 1000 \mathrm{~kg}(1.0 \mathrm{lb} / 1000 \mathrm{lb}) \text { of coke burnoff in } \\
\text { catalyst reyenerator } \\
43 \mathrm{~g} / \mathrm{MJ}(0.1 \mathrm{lb} / \mathrm{MMBtu}) \text { above } 1.0 \mathrm{~kg} / 1000 \mathrm{~kg} \text { due to } \\
\text { fuel combustion in heat recovery device }\end{array}$ \\
\hline & & Opacity & $30 \%$ (except for $16 \mathrm{~min}$. avg. per hour) \\
\hline & & $\mathrm{CO}$ & $0.050 \%$ by volume \\
\hline & & $\begin{array}{l}\mathrm{SO}_{2} \\
\text { fuel } \mathrm{H}_{2} \mathrm{~S} \text { level } \\
\text { Claus plant }\end{array}$ & $\begin{array}{l}230 \mathrm{mg} / \mathrm{dscm}(0.10 \mathrm{gr} / \mathrm{dscf}) \\
0.025 \% \text { by volume of } \mathrm{SO}_{2} \text { and } 0 \% 0_{2} \text { on a dry basis } \\
0.030 \% \text { by volume of reduced sulfur compounds } \\
0.0010 \% \text { by volume of } \mathrm{H}_{2} \mathrm{~S} \text { calculated as } \mathrm{SO}_{2} \text { at } \\
0 \% \mathrm{O}_{2} \text { on a dry basis }\end{array}$ \\
\hline $\begin{array}{l}\text { Subpart } k \text { : Starage } \\
\text { vessels for } \\
\text { petroleum liquids }\end{array}$ & $\begin{array}{l}\text { Vessels with capacity in excess } \\
\text { of } 15,146 \& 140,000 \text { gal) }\end{array}$ & VOC & $\begin{array}{l}\text { Use of floating roof, fixed roof w/internal floating } \\
\text { roof, vapor recovery system, or equivalent system } \\
\text { capable of reducing VOC emissions } 95 \% \text { by weight }\end{array}$ \\
\hline $\begin{array}{l}\text { Subpart } Y: \text { Coal } \\
\text { preparation plants }\end{array}$ & $\begin{array}{l}\text { Plants with capacity in excess of } \\
200 \text { tons/day; thermal dryers, } \\
\text { pneumatic coal-cleaning } \\
\text { equipment, coal processing anc } \\
\text { conveying equipment, coal } \\
\text { storage systems, and coal } \\
\text { transfer and loading systems }\end{array}$ & $\begin{array}{l}\text { TSP } \\
\text { thermal dryer } \\
\text { pneumatic equipment } \\
\text { Opacity } \\
\text { thermal dryer. } \\
\text { pneumatic equipment }\end{array}$ & $\begin{array}{l}0.070 \mathrm{~g} / \mathrm{dscm}(0.031 \mathrm{gr} / \mathrm{dscf}) \\
0.040 \mathrm{~g} / \mathrm{dscm}(0.018 \mathrm{gr} / \mathrm{dscf})\end{array}$ \\
\hline
\end{tabular}


Table 2. New Source Performance Standards for energy projects

(cont inued)

\begin{tabular}{|c|c|c|c|}
\hline Source categorya & Affected facilities & Pollutant & Emission limitb \\
\hline $\begin{array}{l}\text { Subpart GG: } \\
\text { Stationary gas } \\
\text { turbines }\end{array}$ & $\begin{array}{l}\text { Turbines with heat input at peak } \\
\text { load equal to or greater than } \\
10.7 \text { gigajoules per hour based } \\
\text { on lower heating value of fuel } \\
\text { fired }\end{array}$ & $\begin{array}{l}\mathrm{NO}_{x} \\
\mathrm{SO}_{2}\end{array}$ & $\begin{array}{l}\text { Computed accoroing to formulae based on heat rate of } \\
\text { turbine and fuel bound nitrogen } \\
0.015 \% \text { by volume at } 15 \% \text { 02 on a dry basis; sulfur } \\
\text { in fuel limited to } 0.3 \% \text { by weight }\end{array}$ \\
\hline
\end{tabular}

aAs listed in 40 CFR Part 60.

bemission limit cannot be exceeded; joule refers to heat input.

cone 6-minute period per hour of not more than $27 \%$ opacity is al lowed.

dFor fuel derived from lignite or lignite and wood, the emissior 1 imit is $260 \mathrm{ng} / \mathrm{J}(0.60 \mathrm{ib} / \mathrm{MMBtu})$; for fuel derived from North Dakota, South Dakota, or Montana lignite and which is burned in a cyclone-fired unit, the emission limit is $340 \mathrm{ng} / \mathrm{J}$ ( $0.80 \mathrm{lb} / \mathrm{MMBtu})$.

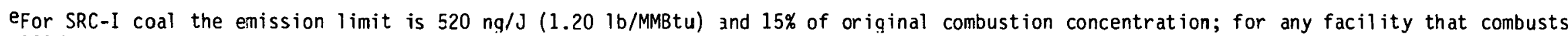
$100 \%$ anthracite coal, or is a resource recovery facility, or $i$ i located in a noncontinental area, the emission limit is 520 ng/J (1.20 ib/MMBtu).

fFor coal-derived qaseous fuels, the emission $1 \mathrm{imit}$ is $210 \mathrm{ng} / \mathrm{J}(0.50 \mathrm{lb} / \mathrm{MMBtu})$.

gFor coal-derived liquid fuels and shale oil the emission limit is $210 \mathrm{ng} / \mathrm{J}(0.501 \mathrm{~b} / \mathrm{MMBtu})$.

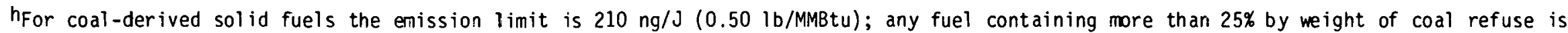
exempt from the $\mathrm{NO}_{\mathrm{X}}$ standards and $\mathrm{NO}_{\mathrm{x}}$ monitoring requirements; for any fuel containing more than $25 \%$, by weight, 1 ignite if the 1 ignite is mined in North Dakota, South Dakota, or Montana, and is combusted in a slag tap furnace the emission 1 imit is $340 \mathrm{ng} / \mathrm{J}$ (0.80 $1 \mathrm{~b} / \mathrm{MMBtu}$ ); lignite not subject to the $340 \mathrm{no} / \mathrm{J}$ heat input emission limit is subject to an emission $1 \mathrm{imit}$ of $260 \mathrm{ng} / \mathrm{J}$ ( $0.60 \mathrm{lb} / \mathrm{MMB}$ tu); subbituminous coal is subject to an emission limit of $210 \mathrm{ng} / \mathrm{J}(0.50 \mathrm{lb} / \mathrm{MMBta})$; bituminous and anthracite coal are subject to an emission $1 \mathrm{imit}$ of $260 \mathrm{ng} / \mathrm{J}(0.6 \mathrm{lb} / \mathrm{MMB} i \mathrm{u})$. 
Unlike the Interpretive Ruling, state and local agencies do not have the option of developing their own, more stringent versions of NSPS based on the federal regulations. NSPS are national emission standards for sources that EPA feels contribute significantly to air pollution. NSPS affect only new sources, because Congress reasoned that these sources had the greatest flexibility to be designed to incorporate the latest and most effective emission control technology. The states may be delegated authority by EPA to implement the NSPS. If such delegation does not occur, then the EPA regional office implements the NSPS. At least thirty-eight states (Appendix B) presently (as of July l, 1981) have authority to implement and enforce portions of the NSPS (40 CFR Part 60). At the request of Congress, EPA has published a prioritized list of 59 major source categories for future NSPS development, many of which may emit significant amounts of volatile organic compounds (VOC). The list, which is updated periodically and published in the Federal Register, is an advance notice of future NSPS development.

\subsection{National Emission Standards for Hazardous Air Pollutants}

The second type of emission standard that could apply to a new or existing source in a nonattainment area is the National Emission Standard for Hazardous Air Pollutants (NESHAP). Section 112 of the CAA requires EPA to 1 ist hazardous air pollutants for which it intends to establish national emissions standards. Within one year of listing a pollutant, EPA must promulgate a standard that provides an "ample margin of safety to protect public health" from the hazardous effects of the pollutant. A hazardous air pollutant is defined in Sect. 112 as an "air pollutant to which no ambient air quality standard is applicable and which in the judgment of EPA may cause, or contribute to, an increase in mortality or an increase in serious irreversible, or incapacitating reversible, illness" (42 U.S.C. 7412).

Since 1970, EPA has listed seven chemicals as hazardous pollutants and has established emissions standards for four of those seven. Table 3 summarizes the four chemicals and their respective emissions standards; the three substances for which standards have not yet been established are benzene, arsenic, and radionuclides (NCAQ 1981). Other chemicals are being considered for regulation by EPA under Sect. 112, and future listings will be published in the Federal Register as they are developed. It is EPA's intent that states implement the NESHAP program as part of their programs for permitting new sources of air pollution. Over 30 states have been delegated authority by EPA to implement the NESHAP program (40 CFR 61.04); these are listed in Appendix $C$.

\section{DOE Compliance}

Figure 1 presents a simplified approach for obtaining an air quality permit in a nonattainment area. The permitting steps shown in $F i g$. 1 are those involving the exchange of information between DOE and the permitting agency. Procedural details are contained in the Environmental Compliance Guide (DOE 1981). Briefly, the permitting process begins with the project manager determining the designated attainment status of the area of interest for each criteria pollutant and preparing a forecast of the air emissions generated by the proposed project. The attainment status designation, together with preliminary emission estimates for the project, determine the pollutants for which a project will undergo review by the regulatory agency. Next, an informal meeting is held between DOE and the appropriate regulatory agency to review the details of a proposed project and to discuss regulations that could potentially affect the project. The appropriate information for the permit application is then gathered by DoE and the application is submitted to the regulatory agency. In general, the agency will grant a permit when it is satisfied that the project would not cause or contribute to a violation of any NAAQS. In a nonattainment area, the agency will grant a permit when it is satisfied that the source will not interfere with demonstrating RFP towards standard attainment.

A review of nonattainment area permitting programs found that from the date of initial submittal of an application to the granting of a permit, the median time for Hirmit nrneessing was from three to five months, denending on the size of the source (Dames and Moore 1981). If air quality modeling is required, or if all ellviluimental impact statement is required before a permit can be issued, then considerably more time would be required for permit approval. For example, monitoring could add a minimum of one year to the time required for permit annroval (ERT 1980). 
Table 3. National Emission Standards for Hazardous Air Pollutants

\begin{tabular}{|c|c|c|}
\hline Pollutant & Affected facilities & Standarda \\
\hline Asbestos & $\begin{array}{l}\text { Asbestos mills, roadway surfacing, manufacturing, } \\
\text { demolition and renovation, spraying, fabricating, } \\
\text { insulating, wastewater treatment }\end{array}$ & No visible emisions to the outside air \\
\hline \multirow[t]{3}{*}{ Beryllium } & $\begin{array}{l}\text { Extraction plants, ceramic plants, foundries, incin- } \\
\text { erators, propellant plants, machine shops processing } \\
\text { beryllium alloy of more than } 5 \% \text { beryllium by weight }\end{array}$ & $\begin{array}{l}10 \mathrm{~g} \text { enission per } 24 \text { hour period, or an ambient } \\
\text { concentration of berillium in the vicinity of a } \\
\text { source of } 0.01 \mathrm{\mu g} / \mathrm{m}^{3} \text { averaged over a } 30 \text {-day } \\
\text { period }\end{array}$ \\
\hline & emissions to the atrosphere & $\begin{array}{l}\text { Time weighted azmospheric jeryllium concentration } \\
\text { of } 75 \mathrm{\mu g} \text { minutes per } \mathrm{m}^{3} \text { of air within the limits } \\
\text { of } 10 \text { to } 60 \text { minutes accumulated during any two } \\
\text { consecutive weeks in any area to. Which an effect } \\
\text { adverse to pub ic health could occur }\end{array}$ \\
\hline & collected enissions (in closed tank) & $2 \mathrm{~g} /$ hour and a maximum of :0 g/day \\
\hline Mercury & $\begin{array}{l}\text { Mercury reconery from ore, chlor-alkali cells for } \\
\text { chlorine gas and alkali netal hydrox:de production } \\
\text { sludge incineration flants, sludge drwing plants for } \\
\text { processing wastewater treatment sludge }\end{array}$ & $\begin{array}{l}2300 \mathrm{~g} \text { per } 24 \text { hour period } \\
3200 \mathrm{~g} \text { per } 24 \text { hour period }\end{array}$ \\
\hline \multirow[t]{4}{*}{ Vinyl chloride } & $\begin{array}{l}\text { Ethylene dichloride plants } \\
\text { ethylene di=hloride purification }\end{array}$ & 10 ppol vinyl chloride: in exhaust gases \\
\hline & axychlorination reactor & $\begin{array}{l}0.2 \mathrm{~g} \text { vinyl chlaride } / \mathrm{kg}(0.0002 \mathrm{lb} / \mathrm{lb}) \text { of } 100 \% \\
\text { of the ethylene dichlloride product }\end{array}$ \\
\hline & Vinyl cnloride plants & $10 \mathrm{ppm}$ vinyl chloride in exhaust gases \\
\hline & Polyvinglchloride plants & $10 \mathrm{ppm}$ vinyl chloride in exhaust gases \\
\hline
\end{tabular}

\footnotetext{
aStandard is not to be exceeded.
}

Source: 40 CFR Part 61 . 


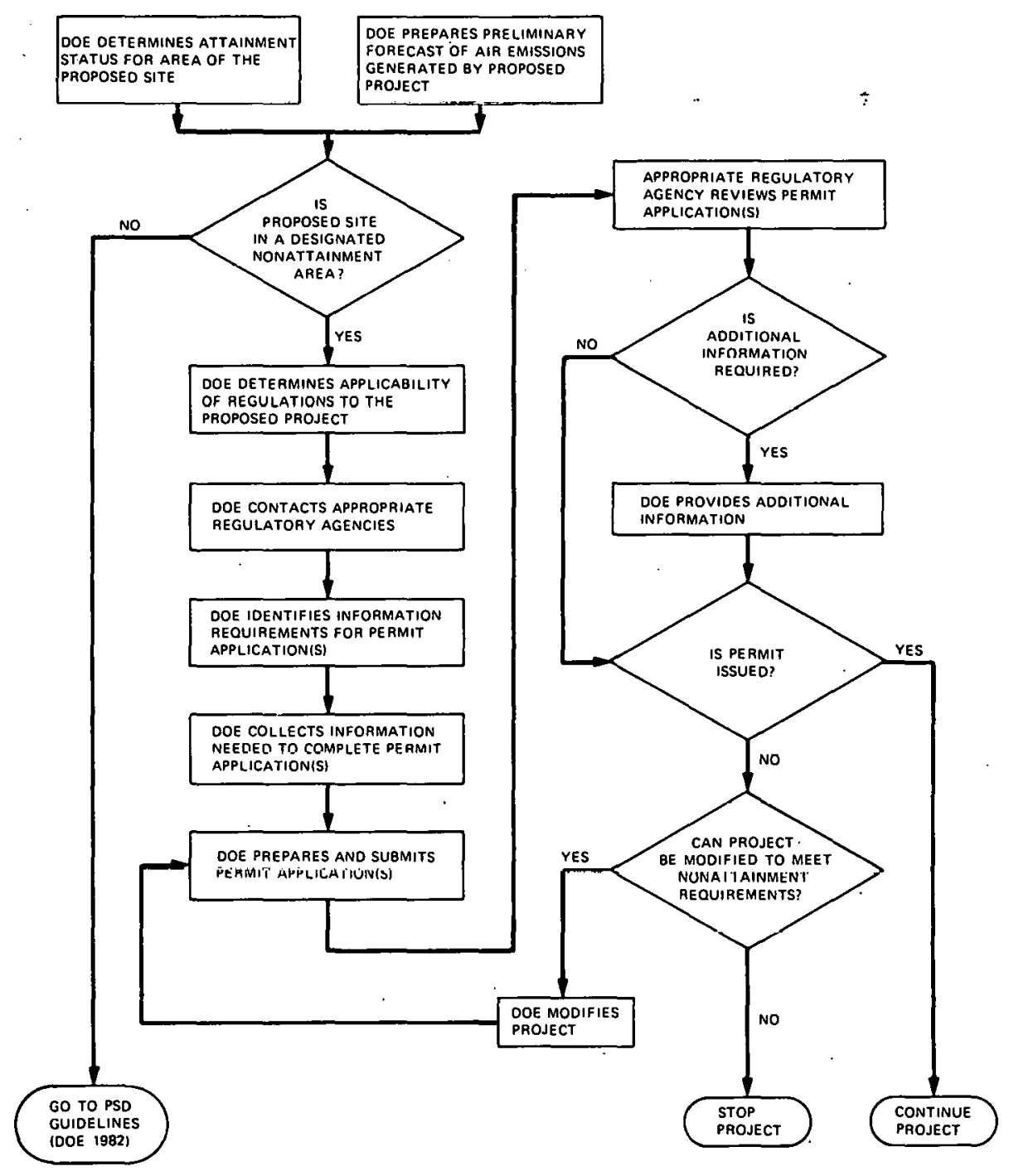

Figure 1. Basic steps for obtaining air permits in nonattainment areas. 
This guidance manual is based on information required to comply with federal regulations. Air quality permitting in nonattainment areas is different from many environmental permitting procedures in that no federal agencies are responsible for issuing the permits; all such permitting is done by state or local pollution control agencies. To base the manual solely on federal requirements for nonattainment area permitting programs would not give a complete picture of the permitting process because under the CAA, any state or local agency may adopt regulations that are more stringent than federal requirements. Therefore, the approach taken in this manual is to discuss the federal requirements for nonattainment areas and then to supplement this discussion with examples from specific state or local permitting programs. A brief survey of state permitting programs in each of the ten EPA regions was conducted to locate information for the discussion; the survey was by no means exhaustive, and consequently, the state and local examples discussed in the manual may not represent the extremes of possible circumstances that a new source could encounter.

\subsection{Dotorminotion of Attainmont Stotus}

Appendix A presents maps of recently designated nonattainment areas in the continental United States. In order to determine the officially designated attainment status of an area, DOE should consult 40 CFR 81.300 et seq. This section of the Code of Federal Requlations lists attainment status of various counties and parts of counties, by pollutant, for each state. The Federal Register should also be consulted to identify recent changes to an area's attainment status. Also, the DOE project manager should contact the appropriate Regional EPA office and state and local air pollution control agencies for information on the current attainment status of a particular site and any pending changes to the designated attainment status. These offices may also be able to define boundaries of sub-county nonattainment areas more precisely. The project manager should note the officially designated attainment status of the area of interest for each pollutant. The guidance in this manual applies to all pollutants for which the area is officially designated by the EPA as nonattainment; guidance in DOE (1982) should be followed for all pollutants for which the area is designated as attainment.

It should be noted that a project locating in a nonattainment area could be subject to Prevention of Significant Deterioration (PSD) regulations and associated information requirements if the proposed site is located near a class I PSD area. Thus, DOE should identify and locate Class I areas near a proposed site and determine if any air quality impact analyses will be required. State and local air pollution control agencies will be helpful in this regard. If the source is close enough to a class I area to warrant an analysis, then the project manager should refer to DOE (1982) for the information requirements for such an analysis.

\subsection{Preliminary Estimates of Emissions}

Preliminary estimates of emissions from the proposed DOE project should be obtained from project engineering staff. The rates of pollutant emissions from smokestacks, process vents, and leaks in valves and flanges should be estimated to the most quantitative extent possible. These emissions can sometimes be estimated from material balances, equipment design or operating data, and published emission factors (EPA 1981) that relate emissions to units of fuel burned or to units of product throughput (EPA 1978). Fugitive emissions, which are defined as "those emissions which could not reasonably pass through a stack, chimney, vent, or other functionally equivalent opening," must be included in the cmission inventory calculations for 27 source categories (45 FR 52746-52748). The categories of the 27 that are of most relevance to DOE interests are coal cleaning plants (with thermal dryers), municipal incinerators capable of charging more than 250 tons of refuse per day, petroleum refineries, fuel conversion plants, chemical process plants, fossil fuel boilers (or combination thereof) totalling more than $264 \mathrm{GJ} / \mathrm{hr}$ ( $250 \mathrm{million} \mathrm{Btu} / \mathrm{hr}$ ) heat inputs, petroleum storage and transfer units with a total storage capacity exceeding $48,000 \mathrm{~m}^{3}$ ( 300,000 bbls). fossil fuel-fired steam electric plants of more than $264 \mathrm{GJ} / \mathrm{hr}$ (250 million Btu/hr) heat input, and any other source which as of August 7,1980 is regulated under Sect. 111 or Sect. 112 of the CAA ( 45 FR 52748), or any other future source.

The definition of the term pollutant requires some discussion at this point, to assist in estimating the proper emission rates. In general, attention should be focused at those pollutants subject to regulation under the CAA or those that could cause a 
nuisance or adverse health effect (EPA 1978). Table 4 lists the 19 pollutants that are regulated under the CAA (i.e., those covered by NAAQS, NSPS, and NESHAP). State or local regulations may govern additional pollutants not listed in Table 1 , but the list should cover most pollutants in most areas of the country. As an example, odorous pollutants, such as organic compounds from the processing of agricultural products (Faith 1977), may cause a community nuisance that requires regulation on the local level (Prokop 1978). Note that for nonattainment areas, only the following criteria pollutants are of concern: sulfur dioxide, particulate matter, carbon monoxide, ozone, nitrogen dioxide, and lead. Areas are not designated attainment/ nonattainment for hydrocarbons because the hydrocarbon NAAQS is merely a guide to attaining the ozone standard.

Emissions should be estimated on a Mg/yr (tons per year) basis to determine compliance with nonattainment area regulations. Emissions profiles, which describe emissions on a short-term basis such as $\mathrm{kg} /$ day for a specified length of $\mathrm{time}$ (e.g., one year), are allowed in some states (Mayer 1982). Federal nonattainment area regulations require that emissions be calculated at the maximum production capacity of the source in question, under its physical and operational design (45 FR 527.46).

\subsection{Applicability of Regulations}

The information discussed in the two preceding sections - designated attainment status and emission estimates - provides the DOE project manager with guidance on gathering information to determine if a given project will be subject to emission regulations. This section describes how to combine the information on attainment status and emissions to provide a preliminary estimate of the regulations affecting a project.

\subsubsection{Preconstruction Review}

Federal nonattainment area regulations contained in 40 CFR $51.18 \mathrm{~J}$ apply to major new sources of air pollution and to major modifications of existing sources. Under the regulations, a major new source in nonattainment areas is one that emits, or has the potential to emit, $91 \mathrm{Mg} / \mathrm{yr}$ [100 tons per year (TPY)] or more of any air pollutant regulated under the CAA (45 FR 52746). "Potential to emit" refers to the maximum capacity of a stationary source to emit a poilutant under its physical and operational design, including the federally enforceable restrictions on the installation of air pollution control equipment, on production, and on hours of operation.

A major modification in nonattainment areas is any physical change in or change in the method of operation of an existing major stationary source that would produce a significant net increase in emissions of any regulated pollutant. Significant is defined as an emissions increase exceeding the following pollutant-specific values: carbon monoxide, $91 \mathrm{Mg} / \mathrm{yr}$ (100 TPY); nitrogen oxides, $36 \mathrm{Mg} / \mathrm{yr}$ ( $40 \mathrm{TPY}$ ); sulfur dioxide, $36 \mathrm{Mg} / \mathrm{yr}$ ( $40 \mathrm{TPY}$ ); particulate matter, $23 \mathrm{Mg} / \mathrm{yr}$ ( $25 \mathrm{TPY}$ ); ozone, $36 \mathrm{Mg} / \mathrm{yr}$ ( $40 \mathrm{TPY}$ ) of volatile organic compounds; and lead, $0.5 \mathrm{Mg} / \mathrm{yI}(0.6 \mathrm{TPY})$ ( $45 \mathrm{FR} 52747$ ).

In order to determine if a modification to an existing major stationary source would be classified as "major", DOE must do the following: (1) determine if the existing source is major [i.e., emissions exceed $91 \mathrm{Mg} / \mathrm{yr}$ (100 TPY)]; (2) add emissions joicreases and subtract emissions decreases occurring because of the modification; and (3) compute the net change in emissions after the modification is brought on line. This'calculation procedure is termed emissions "netting".

The emissions increases and decreases used in the netting calculations must be both "contemperaneous" and "creditable" and must be based on actual emission data. To identify contemporaneous emissions, DOE must first establish a date on which it will commence construction on the modification. It must then identify all changes in actual emissions that have occurred at the source over the five years preceding this construction date. Then, DOE must establish a date on which the emission increases from the modification will occur (i.e., the date on which the modificaton will go on-line). Emission changes that occur before this date but after the five-year period (described above) will be contemporaneous ( 45 FR 52700 ). 
Table 4. Air Pollutants Regulated Under the Clean Air Act

\begin{tabular}{lll}
\hline Asbestos & Fluorides & Ozone* \\
Beryllium & Hydrocarbons* & Particulate Matter* \\
Carbon Disulfide & Hydrogen Sulfide & Sulfuric Acid Mist \\
Carbonyl Disulfide & Lead* & Sulfur Dioxide* \\
Carbon Monoxide* & Mercury & Vinyl Chloride \\
Dimethyl Disulfide & Methyl Mercaptan & \\
Dimethyl Sulfide & Oxides of Nitrogen* & \\
\hline
\end{tabular}

*Denotes Criteria Pollutants.

SOURCE: National Ambient Air Quality Standards ( 40 CFR 50), New Source Performance standards ( 40 CFR 60), and National Emissions Standards for Hazardous Air Pollutants (40 CFR 61). 
All contemporaneous emissions that are creditable must be used in computing net emissions. Emission increases and decreases that had been previously analyzed for air quality impact (as part of an earlier regulatory review) may not be creditable for use in computing net emissions. Any emissions increase is creditable to the extent that the new level of actual emissions at the emissions unit in question exceeds the old actual level of emissions. Any contemporaneous emission decreases (in nonattainment areas) must meet four criteria before they can be considered as creditable for use in calculating net emissions. First, an emissions decrease resulting from shutting down or cleaning up an existing unit cannot exceed the actual emissions from that unit, even if the unit's allowable emissions are much higher than its actual emissions. Also, decreases obtained by bringing a unit into compliance with allowable emissions (those allowed under regulations) are not creditable. Second, all emission decreases must be federally enforceable as of the moment that actual construction begins on the modification in question. Third, an emission decrease is creditable to the extent that it has the same health and welfare significance as the emission increase in question. Fourth, a permitting agency may not credit a decrease to the extent that any permitting authority has already accepted the decrease in satisfying the offset requirements of the nonattainment regulations and consequently has issued a preconstruction permit to a source or modification (45 FR 52702). Emissions decreases used in demonstrating RFP cannot be credited to new sources. In other words, emission reductions may not be "double-counted". Note that some states do not allow netting.

Before October 14, 1981, new major sources and major modifications in nonattainment areas were subject to the dual service definition ( 46 CFR 50766). Under this definition a source is defined as both the entire plant and each piece of process equipment at the plant. Thus, a source could be subject to preconstruction review if the total emissions from the source exceeded the applicable threshold or if emissions from any piece of equipment at the source exceeded the approprlate threshold. The nonattainment definition affords fewer opportunities for a source to use plantwide emission reductions to avoid the need for a permit. On October 14, 1981, the EPA deleted the dual source definition and defined a source in nonattainment areas as an entire plant. However, on August 17, 1982, the D.C. Court of Appeals overturned the October 14 regulations and stated that the EPA must have a more stringent definition of source in nonattainment areas because, in these areas, the agency is attempting to improve poor air quality rather than maintain good air quality. The decision, which, has effectively reinstated the dual source definition, is expected to be appealed by EPA. The case (No. 81-2208) was filed by the Natural Resources Defense Council, Citizens for a Better Environment, and the Northwestern Ohio Lung Association.

Under the federal nonattainment area regulations, major new sources and major modifications to existing sources are subject to regulatory review (and thus the permitting process) for each pollutant emitted in major quantities and for which the area has been designated as nonattainment ( 45 FR 52711). Thus, a new source (or modification) that is major only for $\mathrm{SO}_{2}$ locating in a nonattainment area for particulates and $\mathrm{SO}_{2}$ would be reviewed only for $\mathrm{SO}_{2}$. State and local regulations in nonattainment areas may have different, more stringent (i.e., lower) emission cutoff values for defining major sources and modifications. Some major source thresholds that were found in an informal survey of state and local regulations are summarized in Table 5. The states were selected by contacting each of the ten regional EPA offices and asking them for recommendations of exemplary permitting programs within their region. Each of the recommended state and local agencies was contacted and was asked to send copies of their regulations and permitting procedures. Some states were not included in Table 5 because their regulations did not lend themselves to the organization of the table. Note that some states have no threshold (i.e., their permitting procedure applies to all sources regardless of size). This approach is used by regulatory agencies to develop more accurate stationary source emission inventories. The information in Table 5 may not be the most current values of the emission thresholds. The information was obtained from copies of regulations requested trom state agencies in late 1981 and early 1982, and from regulations published in the most recent version of Environment Reporter (BNA 1982). The threshold values listed in Table 5 are not intended to be exclusively representative of permitting programs in nonattainment areas. 
Table 5. Major Source Thresholds Enforced by State and Local Air Pollutior Control Agencies

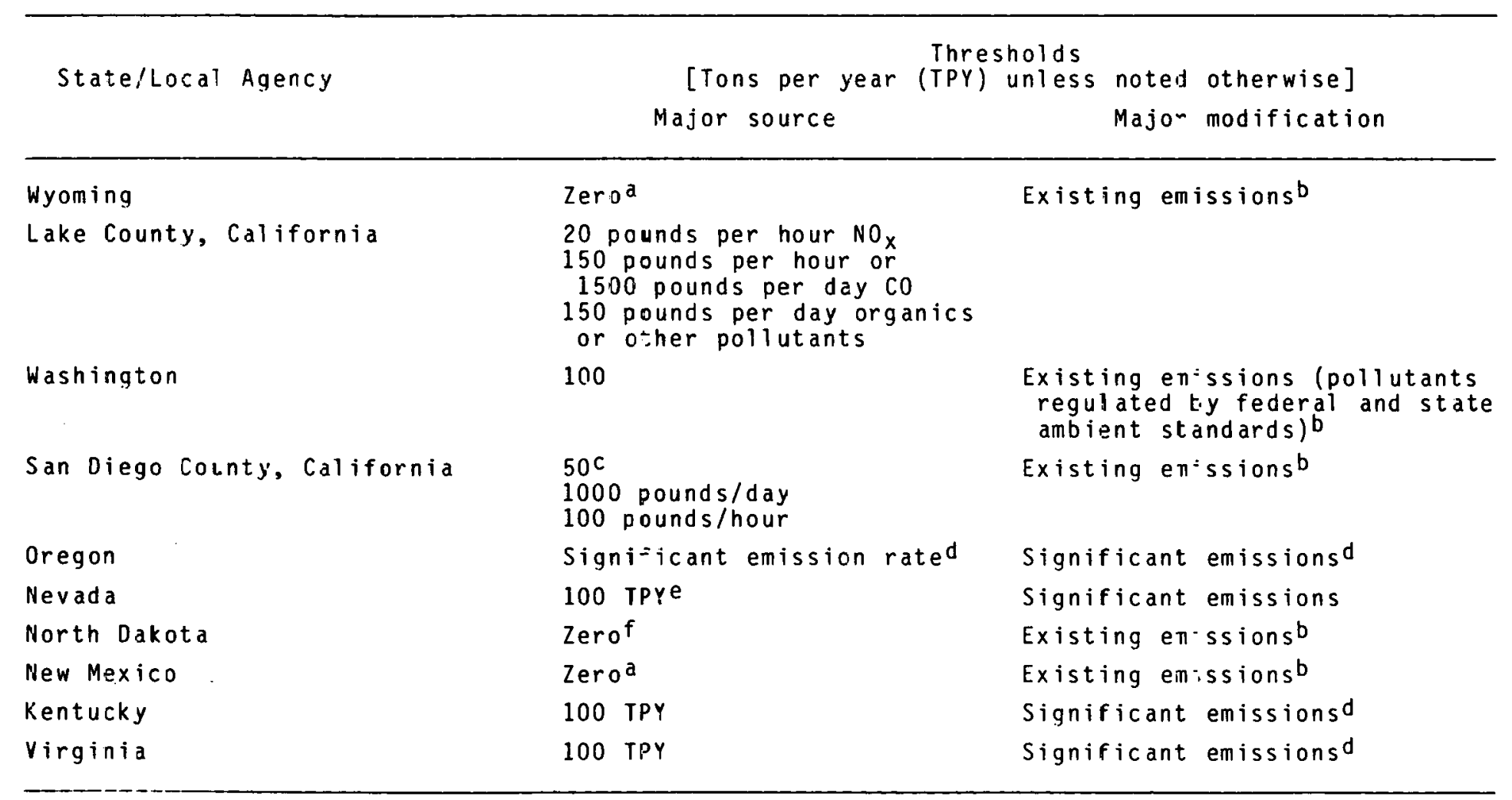

aAll sources, regardless of emission rate, are subject to the regulations.

bany modification increasing emissions above current levels is subject to the regulations.

CWhichever is more restrictive; threshold is 100 TPY for carbon monoxide.

dsignificant emissions are defined as razes equal to or exceeding the following: Co,

100 TPY; NO, 40 TPY; PM, 25 TPY; SO2, 40 TPY; VOC, 40 TPY; Lead, 0.6 TPY; MerCury, 0.1 TPY;

Beryllium 0.0004 TPY; Asbestos, 0.007 TPY; Vinyl chloride, 1 TPY; Fiuorides, 3 TPY;

Sulfuric acid mist, $7 \mathrm{TPY}$; $\mathrm{H}_{2} \mathrm{~S}$, Total reduced sulfur, and reduced sulfur conpounds, 10 TPY.

efor any stationary source 1 isted in Sec. 169 (1) of the Clean Air Act; 250 TPY for other sources.

for source types. designated in state refulations. 


\subsubsection{New Source Performance Standards}

The New Source Performance Standards (NSPS) apply to new sources of the types and sizes of industries specified in 40 CFR Part 60. Applicability of the NSPS does not depend on emissions, but rather it depends on the size or capacity of the source, as measured by fuel consumed, raw materials consumed, production rate, etc. The applicability of NSPS to source types of interest to DOE can be obtained from the second column of Table 2, which lists the sizes of sources subject to NSPS. Because the NSPS are national standards, there are no state or local thresholds that would be used to determine the applicability of the regulations.

\subsubsection{National Emission Standards for Hazardous Air Pollutants}

The National Emission Standards for Hazardous Air Pollutants (NESHAPs) are applicable to new and existing sources of the types and sizes specified in 40 CFR Part 61. Applicability of the NESHAPs does not depend upon emissions, but rather on the size or capacity of the source. The applicability of the NESHAPs to DOE projects can be discerned by examining the second column of Table 3, which lists the facilities affected by the regulations. Because the NESHAPs are national standards, no state or local thresholds exist that would be used to determine the applicability of the regulations.

\subsection{Regulatory Agency Contact}

Initial contact, on an informal basis, with the regulatory agency having jurisdiction over the area of a project's proposed site will help identify the types of regulations that could affect the project and the information needs that could be associated with the permitting process. The DOE project manager can identify the appropriate regulatory agency by locating the appropriate state in Appendix $D$. If the state has delegated permitting authority to county or multicounty districts, then the state agency can refer the project manager to the appropriate local district. A supplementary source of information to Appendix $D$ is the listing of federal, state, and local air pollution control agencies found in the annual directory of "Governmental Air Pollution Control Agencies" published by the Air Pollution Control Association (APCA 1982).

The DOE project manager should bring to the meeting the most current information on the project, including its industrial classification, its size, its estimated emissions, the location of the proposed site, the orientation of the buildings on the site, and regulations that the project manager thinks could apply to the project. The regulatory agency will review the necessary permit application forms with the DOE project manager, will identify applicable regulations, and will estimate the time required for granting of the permit. The agency will also inform the project manager of any permit data requirements that are particularly time-consuming. One of the major reasons for this initial meeting with the agency is to establish contacts for obtaining information and guidance during subsequent steps in the permitting process.

\subsection{Identification of Environmental Information Requirements}

This section identifies and discusses information required to comply with the three types of federal regulations with which DOE could encounter when constructing new sources or modifying existing sources in nonattainment areas: preconstruction review, NSPS, and NESHAP. Most state and local permitting procedures ensure compliance with. these regulations by requiring both a permit to construct and a permit to operate for new sources and modifications, as directed by Congress in Sect. $172(b)(6)$ of the CAA. Both preconstruction review and NESHAP are concerned with permits to construct and operate, whereas the NSPS primarily deal with the permit to operate (although they can be associated with obtaining a permit to construct). All construction permits are Federally enforceable, but only some operating permits are Federally enforceable (Mayer 1982). 


\section{5 .1 Preconstruction Review}

To receive a permit to construct in a nonattainment area under $40 \mathrm{CFR} 51.18 \mathrm{~J}$, projects involving major new sources or modifications are required to:

- reduce emissions to the Lowest Achievable Emission Rate (LAER);

- demonstrate that all other sources owned by the applicant in the state are in compliance with all applicable emission regulations;

- Offset any emissions remaining after attaining the LAER on a greater than one-for-one basis by controlling emissions from existing sources;

- prove the region will continue to demonstrate RFP after the source begins operation.

Complying with these four requirements is accomplished through the preconstruction review process. The remainder of this section discusses information required to comply with the four provisions of 40 CFR 51.18J. Where appropriate, specific examples from state regulations are discussed.

\subsubsection{Information required to determine LAER}

Lowest Achievable Emission Rate (LAER) is defined in 40 CFR $51.18 \mathrm{~J}$ as:

"(i) The most stringent emissions limitation which is contained in the implementation plan of any state for such class or category of stationary source, unless the owner or operator of the proposed stationary source demonstrates that such limitations are not achievable; or

(ii) The most stringent emissions limitation which is achieved in practice by such class or category of stationary source. This limitation, when applied to a modification, means the lowest achievable emissions rate for the new or modified emissions units within the stationary source. In no event shall the application of this term permit a proposed new or modified stationary source to emit any pollutant in excess of the amount allowable under applicable new source standards of performance."

Much research is required to determine LAER, according to a strict interpretation of the LAER definition. In practice, however, state and local permitting agencies have tended to specify LAER based on more readily available information on emission limitations (NCAQ 1981). The National Commission on Air Quality has determined that for source types for which NSPS, Control Techniques Guidelines (CTG), or other formal guidance exists, the permitting agencies tend to specify LAER as that defined by the formal guidance (NCAQ 1981).

NSPS are discussed in Sect. 2.2 of this report and are 1 isted (for energy projects) in Table 3. CTG are recommended emission controls that represent Reasonably Available Control Technology (RACT) for existing stationary sources of volatile organic compounds (VOC). The ozone portion of the SIPs must contain regulations reflecting the application of RACT to those stationary source types for which CTG's have been published. For each source category, a CTG describes the source, identifies the VOC emission points, discusses the applicable control methods, analyzes costs required to implement the control methods, and recommends regulations for limiting VOC emissons from the source. Appendix $E$ contains a listing of published CTG documents and their corresponding EPA report numbers.

A rule of thumb that can be used to obtain a rough estimate of the degree of control required for LAER is the emission limit established by the NSPS or CTG for the particular source category. A compilation of LAER determinations published by EPA for :various source types (Wunderle 1980) may also be useful in gauging the level of emission control needed to comply with the regulations. The DOE project manager should maintain 
close communication with the permitting agency regarding the determination of LAER for the project of interest.

If the dual source definition is maintained for nonattainment areas, DOE could be required to define LAER for each piece of process equipment exceeding the applicable threshold, in addition to defining LAER for the entire plant. Attaining the LAER is required only for those pollutants for which the increased allowable emissions (those calculated using the maximum rated capacity of the source and the most stringent of NSPS, NESHAP, SIP limit, or federally enforceable permit conditions) exceed $45 \mathrm{Mg} / \mathrm{yr}$ ( $50 \mathrm{TPY}), 454 \mathrm{~kg} / \mathrm{d}$ ( $1000 \mathrm{lbs} / \mathrm{d}$, or $45 \mathrm{~kg} / \mathrm{hr}(100 \mathrm{lbs} / \mathrm{hr}$ ), although the reviewing authority may address other pollutants. The preceding hourly and daily rates apply only to pollutants for which a $24-h r$ (or shorter time period) NAAQS has been established.

\subsubsection{Sources in compliance}

A second condition that must be met to fulfill federal requirements for permitting in nonattainment areas is the certification by DOE that all other major sources under its jurisdiction (owned or operated by DOE) in the same state as the proposed source are in compliance with all applicable emission limitations and standards under the CAA, or are in compliance with an expeditious schedule that is federally enforceable or contained in a court decree. The state air pollution control agency would be the best source for this information.

\section{5 .1 .3 offsets}

Pollutant emission rates after LAER is achieved must be offset on a greater than one-for-one basis by reducing emissions from existing sources in the area of the proposed project, or by using a growth allowance provided by the state (in which the state "gives" the offsets of the source). Emission offsets must involve the same criteria pollutant. For example, particulate emissions may not be offset by sulfur dioxide emissions. Reducing hydrocarbon emissions of low photochemical reactivity and increasing emissions of high reactivity is not allowed (see, for example, 42 FR 35314 , 45 FR 32424, and 45 FR 48341).

Only surplus emissions may be used in offset arrangements (47FR 15076). Surplus emissions are those not currently required by law, and are defined with respect to a baseline established by state air pollution control agencies. The DOE project manager should determine what the baseline emissions level is for the particular source type in question, and also what units are used to define the baseline (actual emissions or allowable emissions), by contacting the appropriate state or local regulatory agency.

Any emission reduction that is negotiatied as part of an offset arrangement must be both federally enforceable and permanent. To ensure enforceability, the DOE project manager, in conjunction with the state agency, should verify that any offset arrangement was conducted as a SIP revision, generic rule action, or permit requirement (47 FR 15076). Permanence is generally assured by requiring changes in source permits to reflect a reduced level of permissible emissions ( 47 FR 15076).

offsets must also be quantifiable, in terms of measuring the amount of emission reductions and characterizing the reduction for future use. For preconstruction review of new sources, $D O E$ would probably estimate emissions, and corresponding reductions, with emission factors (EPA 1981). Because all of the reductions involved in an of fset arrangement must be quantified in the same manner ( $47 \mathrm{FR} 15076$ ), DOE would be required to estimate emissions from the source of offsets using emission factors also. For modifications to existing sources, emission reductions could be quantified by stack tests or continuous monitoring. The DOE project manager should refer to 40 CFR Parts 60 and 61 for approved procedures to be used in conducting stack tests and monitoring for various pollutants.

In general, emission offsets should be made on a $\mathrm{kg} / \mathrm{hr}$ (lbs/hr) basis when all facilities involved in the emission offset arrangement are operating at their maximum expected or allowed production rate. Other averaging periods may be allowed by the reviewing agency in addition to pounds per hour. If Mg/yr (TPY) are used, the baseline emissions for existing sources providing the offsets should be calculated using the actual annual operating hours for the previous one or two year period (or other period if warranted by cyclical business conditions). 
The location of the offsetting emissions is closely related to the air quality benefit that will result from the arrangement. Consequently, restrictions on the location of the offsets have been established. In general, all offsets should be obtained as close to the proposed source as possible; the farther away the offsets are located from the source, the greater should be the emission offsets required. In the case of emission offsets involving volatile organic compounds and nitrogen oxides in ozone nonattainment areas, the Emission offset Intrepretive Ruling ( 40 CFR Part 51 , Appendix S) requires that offsets be obtained anywhere in the "broad vicinity" of the proposed new source. Offsets will be acceptable if obtained from within the same AQCR as the new source or from other areas that may be contributing to the ozone problem at the location of the proposed new source. Offsets within a "broad vicinity" are acceptable because ozone and $\mathrm{NO}_{2}$ nonattainment areas tend to be regional, rather than localized, problems that are not as dependent on specific voc or NO $\mathrm{N}_{x}$ source locations as they are on overall area emissions. On the other hand, the air quality impacts of sulfur dioxide $\left(\mathrm{SO}_{2}\right)$, particulate matter (PM), and carbon monoxide (CO) sources are site dependent, and simple area wide emisslun uffsets are not appropriate. Thus, emission offsets for $\mathrm{SO}_{2}, \mathrm{PM}$, and co sources should be obtained from an existing source on the same premises or in the immediate vicinity of the proposed new source such that a net air quality benefit (see next section), as confirmed with atmospheric dispersion modeling, occurs.

If demonstrating RFP for the region in question is based on actual emissions, then all offset arrangements must be based on actual emissions. If RFP is based on allowable emissions (those emission levels described by permits), then either actual or allowable emissions may be used in offset arrangements (Mayer 1982).

Examples of state and local permitting procedures illustrate the types of offset requirements that a DOE project manager could encounter. Table 6 summarizes offset ratios required by some state and local regulatory agencies. The wide variability in offset ratios is of interest. Ratios range from "greater than $1: 1$ " to that computed with a formula expressing the ratio as a function of distance between sources. Several state regulations surveyed were found to contain no numerical offset ratio requircments; these states required only that emissions after the new source begins operation be less than those existing prior to the new source.

The reviewing authority may allow banking of emissions; that is, if a new source obtains emission reductions from existing sources that exceed those required for reasonable progress toward attainment, these emissions may be saved for use in future offset arrangements. The owner of an existing source may reduce emissions beyond those required by the SIP for use in providing future offsets. Banked offsets may be used in a preconstruction review program as long as the banked emissions are identified and accounted for in the SIP control strategy. The reviewing authority should identify and account for the banked emissions in a SIP revision or a permit, and establish rules for the use of banked emissions, in order to preserve the banked offsets. DOE should contact the appropriate agency to obtain information on the applicable banking rules.

If DOE creates an emission reduction for deposit in an emission bank, the project manager may be required to provide information to evaluate the proposed use of an emission reduction. This information could include the location of the source creating the reductions, its stack parameters, the temperature and velocity of its plume, particle size of emissions, the existence of any hazardous pollutant emissions, daily and seasonal emission rates, and any other data that might be necessary to evaluate future use of the emission credits (4/ FR 15084). For example, Llie emissions bank in Jefferson County, Kentucky requires a variety of information for banking; DOE would need to complete all items denoted by an " $X$ " in the form shown in $F 1 g .2$ for each source of banked emissions. This ledger is then maintained by the Jetiferson Lounty Alr Pullullull Control District to track the emission reductions. The Banking Application Information form that is used by the Bay Area Air Quality Management District requires less information than the form in Fig. 2; the applicant only needs to provide the company name, contact, location of proposed reductions, and emission reductions (expressed as tons/year annual average) applied for (Phillips 198l).

If DOE wants to withdraw emission reductions from an existing bank, it may be required to submit information on the location of the source using the offsets, the purpose of the offsets, the pollutants being offset, and the effect of the use of the banked emissions on ambient air quality. In terms of information requirements, using a public emissions bank may be less demanding than using internal offsets or negotiating 
Table 6. Example Emission Offset Ratios Required by Various State and Local Air Pollution Control Agencies

Michigana

San Diego County, Californiad

Washingtona

Missouria

Coloradoa

Bay Area Air Quality Managementb

District, San Francisco, Cal ifornia

San Diego County, Californiac

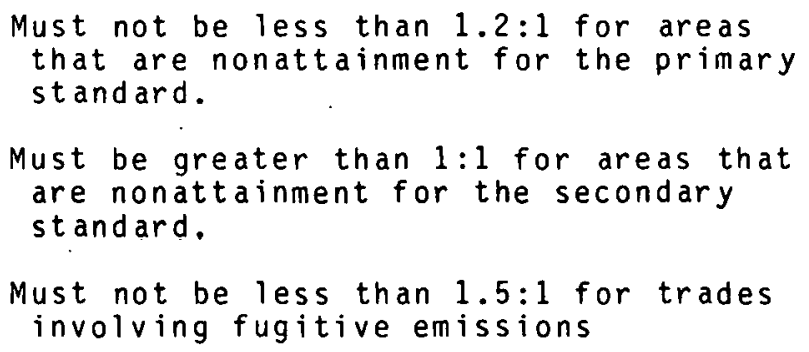

Must not be less than $1.2: 1$

$1.3: 1$

Must be greater than 1:1 if no growth increment is allowed

$1: 1$ if growth increment is allowed

Must be greater than $1: 1$

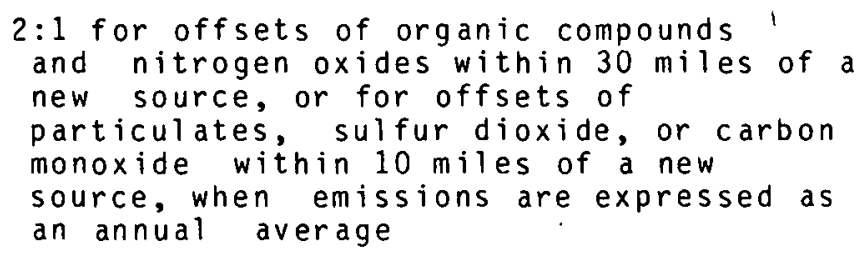

1.2:1 for offsets of organic compounds and nitrogen oxides within 15 miles of a new source or for offsets of particulates, sulfur dioxide, or carbon monoxide within 5 miles of a new source

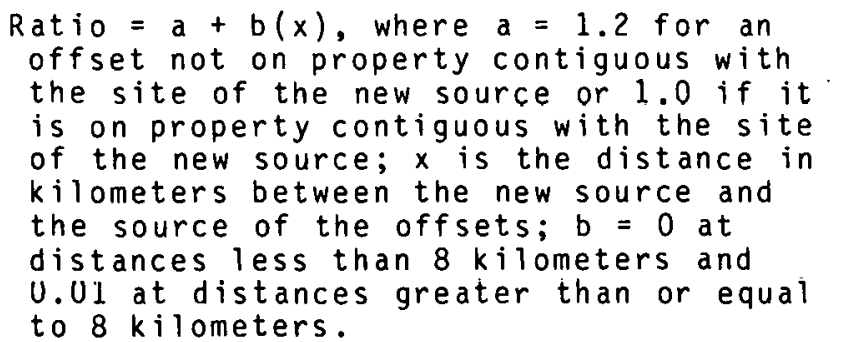

aSource: State or local regulations.

bsource: Phillips, 1981.

c Source: Liroff, ig80. 
Figure 2.

$X:$ DOE PROVIDES

BAHKED EMISSIONS LEDGER

AC T I VE

JEFFERSON COUNTY AIR POLLUTION

CONTROL DISTRICT

x 1. Pollutant Description

2. Deposit Code $\square \square \square \square \square-\square \square \square$

3.a. Date of Deposit b. Closing Date

$x$ 4.a. Depositor of Banked Emissions

$x$ b. Address c. PI ant EIS

d. Company that generated emission reduction

e. Previous deposit codes for these emissions

$x$ 5.a. Description of process generating banked emissions and permit numbers

$x$ b. What caused emissions to be available for banking?

x 6. Banked emissions prior to discounting

7. Initial discount

8. Balance (subtract Line 7 from Line 6)

For further explanation see Note Nos.

First Withdrawal

9. Date Buyer

10. Emissions from source requiring offsets (but before applying offset ratio)

11. Offset ratio $: 1$

12. Offset emissions (multiply line 10 by Line 11)

13. Balance (subtract Line 12 from Line 8)

For further explanation, see Note nos.

Permit No.

Tons/yr Tons/yr Tons/yr

Second Withdrawal

14. Date Buyer Permit No.

15. Emissions from source requiring offsets (but before applying offset ratio)

16. Offset ratio $: 1$

17. Offset emissions (multiply Line 15 by Line 16

18. Balance (subtract Line 17 from Line 13)

For rurther explanation, sce Note nos.

Third Withdrawal

19. Date Buyer Permit No.

20. Emissions from sourco requiring nffsets (but before applying offset ratiol

21. Offset ratio $: 1$

22. Offset emissions (multiply Line 21 by Line 22)

23. Balance (subtract Line 23 from Line 19)

Enter here and on Line 24 , page 2

Tons/yr Tons/yr

For further explanation, see Note nos. 


\section{Fourth Withdrawal}

25. Date

Buyer

Permit No.

26. Emissions from source requiring offsets (but before applying offset $r$ atio)

27. Offset ratio $: 1$

28. Offset emissions (multiply Line 26 by Line 27)

29. Balance (subtract Line 28 from Line 24)

For further explanation, see Note nos.

Tons/yr
Tons/yr
Tons/yr

\section{Fifth Withdrawal}

30. Date Buyer

Permit No.

31. Emissions from source requiring offsets (but before applying offset ratio)

32. Offset ratio $: 1$

33. Dffset emissions (multiply Line 31 by Line 32)

34. Balance (subtract Line 33 from Line 29)

For further explanation, see Note nos.

No .

NOTES 
Figure 2. (continued)

E M I S S I O H S B A N K D A T A E N T R Y*

Source Name

Address

Page

Completed by

Oate

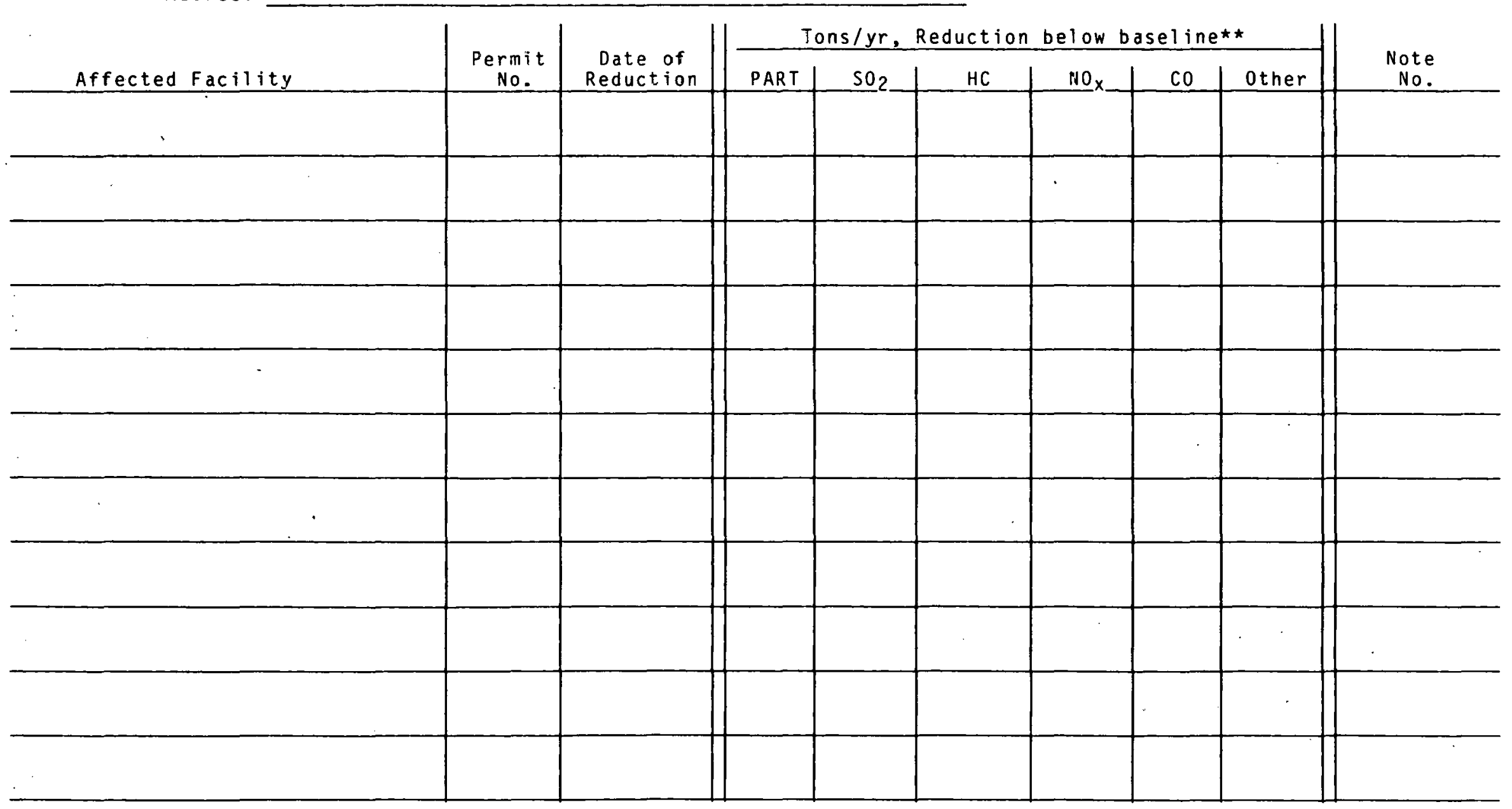

* DOE provides all information on this form.

** See District Regulation 2.12, Note: S02 SIP attainment strategy is based on allowable emissions.

SIP attainment for the other pollutants is based on actual emissions. The base year varies.

Source: Reproduced from form 266-B provided by the Jefferson County Air Pollution District, Louisville, ky. 
external offsets because DOE would not need to submit information to the regulatory agency proving the legality of the emissions. Additional information on banking may be found in EPA (1980a).

If no emission offsets are available through public emission banks, DOE should examine the feasibility of obtaining offsets at its own facilities. In formulating internal offsets, $D O E$ should be certain that all sources used in the offset arrangement are in compliance with all applicable regulations and that any further reductions in emissions at the facilities were not already accounted for in the SIP by the state agency. Close communication with the air regulatory agency may be useful in this regard. DOE also needs to know the appropriate offset ratio, any restrictions on distance between a source and its emission offsets, and the baseline emissions for determined offsets. Lastly, if no public bank is available and no internal offsets are possible, DOE would need to negotiate external offsets. To do so, DOE would first need to locate potential sources of offsets within the distance restrictions established by the regulatory agency. Next, DOE would need to identify the pollutants emitted and the emission rates from the potential offset source. The baseline for emission offsets would need to be established by contact with the appropriate regulatory agency. DOE would then need to negotiate the offsets with the owner of the offset source, and any negotiated transactions would require approval by the regulatory agency.

It is important to note that offset arrangements could add considerable time to the permitting process because approval of the arrangement by a state agency could require a SIP revision. In lieu of revising the SIPs, states now have the option of adopting generic rules, in which the SIP is revised for one source type, and future sources need not go through the SIP revision process for approval of offset arrangements (47 FR 15076). Use of generic rules instead of SIP revisions would simplify the permitting process.

If DOE has a project in a state that uses growth allowances to offset emission increases from new sources, then the information needed to meet the offset requirement will be reduced because the state will "give" the offset to DOE. With growth allowances, the state knows the maximum increase in emissions that can occur in a nonattainment area while still demonstrating RFP, and it apportions these increases to new sources as permit applications are filed.

Net AIr Quality Benefit. DOE must prove that any emissions offsets negotiated for a given project will result in a "positive net air quality benefit" in the affected area. In nonattainment areas, use of offsets cannot create a new violation of an ambient standard or prevent the planned removal of an existing violation. For offsets involving $V O C$ or $N O_{x}$, whose impacts occur across broad geographic areas, kilogram-for-kilogram reductions and increases in emissions can be assumed to be equal in ambient effect, and a net air quality benefit does not need to be demonstrated. Ambient considerations are critical for offsets involving $\mathrm{sO}_{2}$, particulates, or carbon monoxide, whose air quality impact may vary with location of the source of emissions.

offset transactions must demonstrate ambient progress (i.e., progress towards attainment of the ambient standards). This demonstration is typically made through mathematical dispersion modeling that predicts the ambient impact of emissions. A three tier approach to modeling is being authorized by EPA in which the degree of modeling required is linked to the likely ambient impact of the proposed offset arrangement. The more complex modeling exercises will require more information on the part of DOE. Thus it is to DOE's advantage to perform no more sophisticated modeling than is required. The three tier approach can be summarized as follows ( $47 \mathrm{FR} \mathrm{15076):}$

Level 1: No modeling is needed if the proposed TSP, $\mathrm{SO}_{2}$, or $\mathrm{CO}$ trade does not result in a net increase in applicable baseline emissions, if the emission sources are located in the same immedicate vicinity, and if no increase in emissions occurs at a lower effective plume height.

Level II: Limited modeling involving the specific emission sources in the trade is needed for trades not included in Level $I$ if there is no net increase In applicable baseline emissions and if emissions after the trade will not cause a significant air quality impact at the receptor of maximum predicted impact. States may us the following pollutant levels to judge a significant impact: $10 \mu \mathrm{g} / \mathrm{m} 3$ for the 24 hour TSP standard; $13 \mu \mathrm{g} / \mathrm{m} 3$ for the 24 hour $\mathrm{SO}_{2}$ standard; and $575 \mu \mathrm{g} / \mathrm{m} 3$ for the 8 -hour CO standard. 
Level III: Full dispersion modeling, considering all sources in the area of impact, is required if net applicable emissions will increase as a result of the trade (which can't legally occur under the federal offset arrangements) or if the trade will have a significant impact on air quality at the receptor showing the maximum ambient impact.

In general, dispersion modeling will require the selection of a model and the gathering of local and regional emissions data, background pollutant levels, meteorological data, and topographical information for the general area of a proposed site. Model selection should be done with the assistance of the applicable state or local regulatory agency; EPA guidelines on air quality models (EPA 1980b) may be useful in this regard. Local and regional emissions data should be available from the state or local regulatory agency; these data could also be found in the nonattainment area plan for the area of interest. Background pollutant levels are available from state and local monitoring programs carried out by the regulatory agencies; many of these data are also published by EPA. Meteorological data collected at National Weather Service Stations are available in hard copy or computer magnetic tape format from the National Climatic Center in Asheville, North Carolina. Limited meteorological data are also available from airports. Topographical information can be obtained from quadrangle maps published by the United States Geological Survey.

Demonstrating that a net air quality benefit will result from offset arrangement is required only for those pollutants for which the increased allowable emissions exceed $45 \mathrm{Mg} / \mathrm{yr}$ (50 TPY), $454 \mathrm{~kg} / \mathrm{d}$. (1000 lbs/d), or $45 \mathrm{~kg} / \mathrm{hr}$ (100 lbs/hr), although the reviewing authority may address other pollutant emissions if deemed necessary. The preceding rates apply only to those pollutants for which a $24 \mathrm{hr}$ or less NAAQS has been established (see Table 1).

\subsubsection{New Source Performance Standards}

Compliance with New Source Performance Standards (NSPS) is generally required before a new source is issued a permit to operate. It is important to note that a source receiving a permit in a nonattainment area most likely will already have complied with the NSPS emission limit because in theory meeting the LAER requirements means that emissions from the source are at least as stringent as the NSPS limitations. The information required to comply with the NSPS usually consists of preliminary notification requirements, emission measurements (stack tests or continuous monitoring), reporting of emission data to the appropriate regulatory agency, and recordkeeping of the data. Typically, the emission measurements to determine compliance with NSPS are made after the shakedown period of a new source.

Notification requirements for complying with the NSPS are contained in 40 CFR 60.7 and are summarized in Table 7. Requirements for emission measurements vary according to the NSPS and the pollutant. Table 8 summarizes the monitoring requirements for the NSPS that are likely to be of most interest to DOE project managers (see Table 2). In general, two types of emission measurements are made. Performance tests are stack measurements conducted not later than 180 days after startup but winin 60 days after achieving the maximum production rate. The pollutant measurements made during the stack tests are used to determine compliance with the NSPS. Continuous emission monitoring (CEM) is required for certain pollutant emissions and from specified source types. The data collected by the CEM meet the performance test requirements and thus are used to determine NSPS compliance. Details of the performance tests and the CEM procedures are too detailed to 1 ist here, and the reader is referred to the appropriate NSPS in 40 CFR Part 60 for more information.

Once emission data have been collected, various data reporting requirements must be met to comply with the NSPS. Most of the recordkeeping requirements pertain to the facility after it has received a permit and has begun operation. Records should be maintained by DOE of the occurrence and duration of any startups, shutdowns, or malfunctions in operation of the facility, air pollution control equipment,. or continuous emission monitoring system. Quarterly progress reports on excess emissions (defined separately for each NSPS), as recorded by monitoring devices, should also be submitted by DOE. DOE should also maintain a file of all emissions measurements, including CEM data and monitoring device performance test data, for a period of two years. 
Table 7. Notification Requirements for NSPS Compliance

\begin{tabular}{|c|c|}
\hline Information Required in Written Notification & Deadline \\
\hline $\begin{array}{l}\text { Date that construction of an affected facility* } \\
\text { is commenced }\end{array}$ & $\begin{array}{l}\text { No later than } 30 \text { days after } \\
\text { such date }\end{array}$ \\
\hline $\begin{array}{l}\text { Anticipated date of initial startup of an } \\
\text { affected facility. }\end{array}$ & $\begin{array}{l}\text { No more than } 60 \text { days nor less } \\
\text { than } 30 \text { days prior to such } \\
\text { date }\end{array}$ \\
\hline $\begin{array}{l}\text { Actual date of initial startup of affected } \\
\text { facility }\end{array}$ & Within 15 days after such date \\
\hline $\begin{array}{l}\text { Physical or operational change to existing facility } \\
\text { that may increase emission rate of any. pollutant }\end{array}$ & $\begin{array}{l}60 \text { days or as soon as } \\
\text { practicable before the } \\
\text { change is made }\end{array}$ \\
\hline $\begin{array}{l}\text { Date upon which demonstration of performance of } \\
\text { continuous monitoring system commences }\end{array}$ & $\begin{array}{l}\text { Not less than } 30 \text { days prior } \\
\text { to such date. }\end{array}$ \\
\hline
\end{tabular}

* See column 2 of Table 2 for affected facilities for energy related projects. 
Table 8. Monitoring Requirements Associated with New Source Performance Standards for Energy-Related Projects

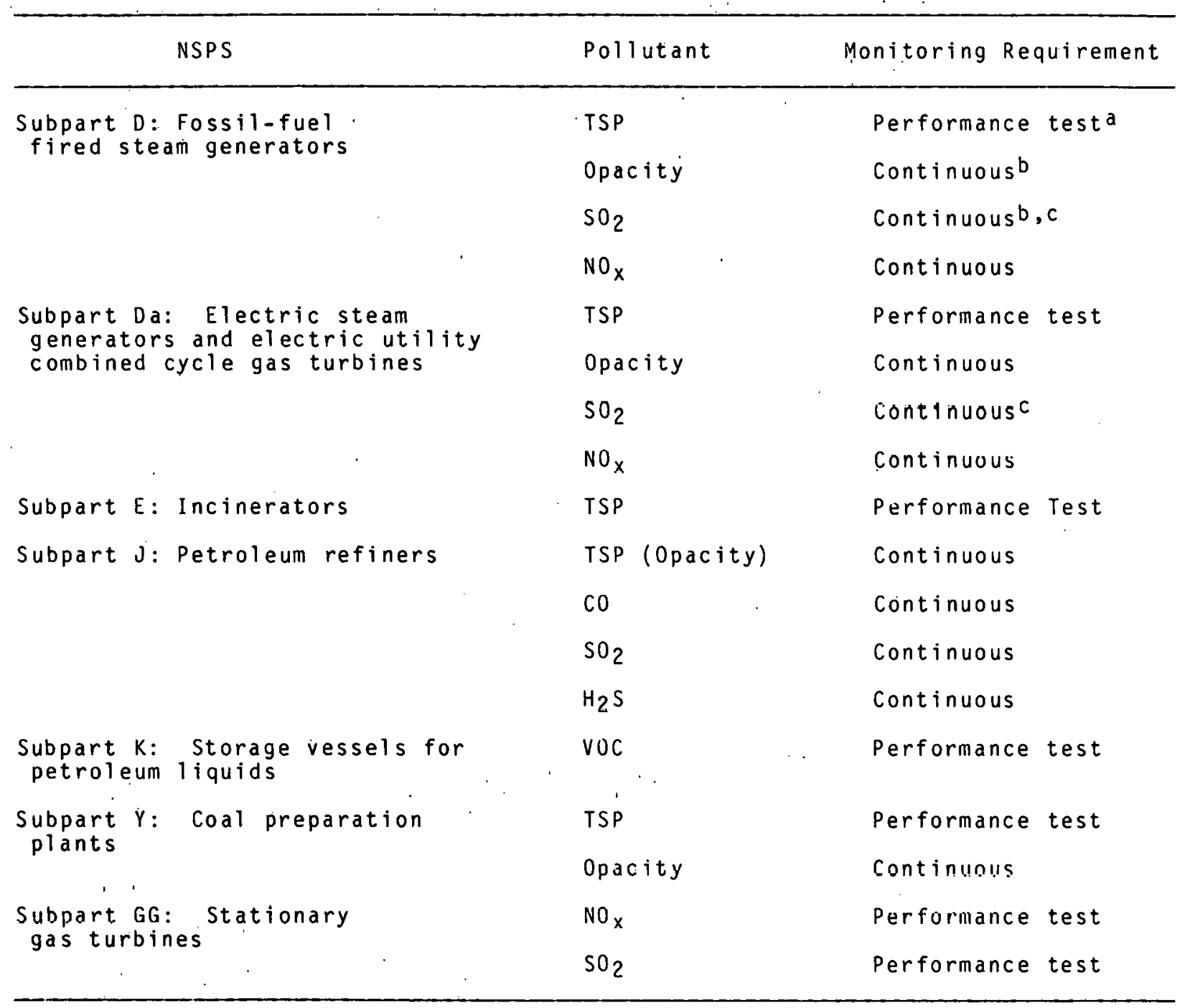

aperformance test criteria are published for each NSPS in the appropriate Subpart of 40 CFR Part 60 .

bNot required for gaseous fuel combustion.

c Continuous monitoring not required if no $F G D$ device is present and if the owner/operator monitors $\mathrm{SO}_{2}$ by fuel sampiing and analysts. 


\subsubsection{National Emission Standards for Hazardous Air Pollutants}

As part of the application for a permit to construct, DOE must submit information to comply with the National Emission Standards for Hazardous Air Pollutants (NESHAP). Under 40 CFR 61.07 the owner or operator of any new source or modification subject to the NESHAP (see column 2 of Table 3 ) must submit to EPA an application for construction or modification; in general, this application shall include the following information:

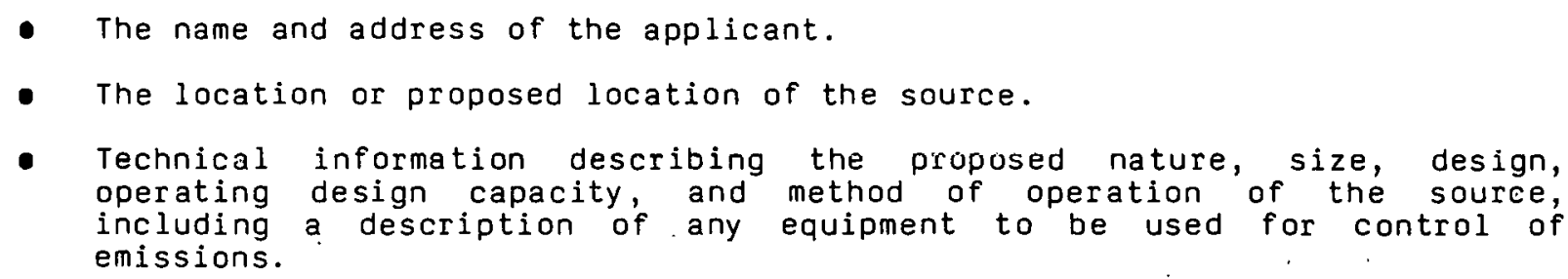

Such technical information shall include calculations of emission estimates in sufficient detail to permit assessment of the validity of such calculations. The above information must be submitted prior to the date on which the construction or modification is planned to commence, or within 30 days after the effective date (date at which a NESHAP becomes effective) in the case of a new source that has begun construction or modification, but that has not yet begun operation. If a DOE source is expected to begin operation after the effective date of a NESHAP, then DOE must inform the appropriate regulatory agency of the anticipated startup of the source not more than 60 days nor less thian 30 days prior to the startup, and of the actual date of initial startup within 15 days after such date.

If a DOE project involves an existing source that is subject to the NESHAP, Or a new source that began operation before the effective date of a NESHAP, then DOE must submit the following information to the appropriate regulatory agency within 90 days of the date the NESHAP becomes effective:

- Name and address of the owner or operator.

- The location of the source.

- The type of hazardous pollutants emitted by the stationary source.

- A brief description of the nature, size, design, and method of operation of the stationary source including the operating design capacity of such source. Identification of each point of emission for each hazardous pollutant.

- The average weight per month of the hazardous materials being processed by the source, over the last 12 months preceding the date of the report.

- A description of the existing control equipment for each emission point.
(•) Primary control device(s) for each hazardous pollutant.
(•) Secondary control device(s) for each hazardous pollutant.
(•) Estimated control efficienry (perrent) for each control device.
- A statement by the owner or operator of the source as to whether he can comply with the standards prescribed in this part within 90 days of the effective date.

A waiver of compliance with a NESHAP may be requested (in writing) by DOE if the project is unable to comply with the standard within the 90 day period. The waiver may be allowed for a period not exceeding two years from the effective date of the standard. The written request should include the following information: 
- A description of the controls to be installed to comply with the standard.

A compliance schedule, including the date each step toward compliance will be reached. Such list shall include as a minimum the following dates:

(•) Date by which contracts for emission control systems or process modifications will be awarded, or date by which orders will be issued for the purchase of component parts to accomplish emission control or process modification;

(a) Date of initiation of onsite construction or installation of emission control equipment or process change;

(e) Date by which onsite construction or installation of emission control equipment or process modification is to be completed; and

(a) Date by which final compliance is to be achieved.

A description of interim emission control steps which will be taken during the waiver period.

3.6 Permit Applications

The discussion to this point has focused on federal requirements for compliance with regulations applicable to DOE projects locating in nonattainment areas. Because these regulations are implemented on the state or local level, other information needs may exist that have been added into the state or local permitting system to address various local concerns not specifically required in Part $D$, Title I of the CAA. $A$ discussion of all of the state permitting programs and their unique information requirements is clearly beyond the scope of this document. To completely ignore the specifics of local permitting programs, however, does not provide an adequate picture of information requirements associated with air quality permitting. This section will, therefore, discuss selected state and local permit requirements and will provide some idea of the types of information that could be required to secure an approved permit.

Many state and local agencies have permit applications that vary with the type of source. As an example, Fig. 3 presents a "general" type of permit application that is used for fuel burning equipment (although not necessarily exclusively in nonattainment areas) (EPA 1978). As can be seen by 1nspection of Fig. 3 , most of the information needs are straightforward and should be readily obtainable from a project engineer.

To provide information on the types of information that could be required in a permit application, state and local regulations were surveyed. Table 9 presents a summary of broad types of information that could be required in the context of permitting programs. The summary is not intended to represent requirements unique to nonattainment area permitting, nor is it intended to present an exhaustive survey of regulations. Rather, the purpose of the table is to illustrate the types of requirements that are not explicitly stated in Title I Part $D$ of the CAA but can and do appear in permitting programs. Some of the more unique requirements include: the method of process and air pollution control equipment waste disposal, as required by Michigan, Missouri, and Lake County, California; a plan for reducing emissions during air poliution episodes or emergencies, as required by Michigan and Alaska; and information necessary for the preparation of environmental assessment documents, as required by Michigan and New Mexico.

\subsection{Exemptions from Reguletory Review}

Under EPA's recent Emissions Trading Policy Statement (47 FR 15076) DoE could reduce the information required for compliance with the CAA by exempting projects from regulatory review. This exemption is achieved by reducing emissions below the appropriate threshold (see Sect. 3.3) for new sources and modifications. The technique of netting, in which plant-wide emissions from a modification are reduced to an insignificant total (see Sect. 3.3), may be used to exempt a modification of an existing plant from preconstruction review permits and associated requirements, including monitoring, modeling, installation of control technology to meet the LAER, and the 


\section{FUEL BURNING EQUIPMENT}

(Boilers, Heaters, and Steam Generators)

1. Manufacturer Model No.

2. Your identification Year installed

3. Input capacities $\left(10^{6} \mathrm{BTU} / \mathrm{hr}\right)$ : Output capacities (lb-steam $/ \mathrm{hr}$ ): Note: Indicate units if different from above.

Rated $\longrightarrow$ Max. Max. ${ }_{\text {Roted }} \longrightarrow$ Normal -

4. Percent used for: Space heat $\% \quad$ Process $\%$ Power_— $\%$

5. Normal Operating schedule: $\mathrm{hr} / \mathrm{day}$, day/wk $w k / y r$

6. Type of fuel fired:

$\square$ Coal $\square$ Oil

$\square$ Wood $\square$ I.PG

$\square$ Natural gas $\sqcap$ Other, specify

7. Type of draft:

$\square$ Natural

$\square$ Induced

$\square$ Forced.

8. Combustion monitoring: $\square$ Fuel/air ratio $\square$ Other, specify $\square \mathrm{O}_{2}$ $\square$ Smoke

\section{COAL-FIRED UNITS}

9. Type of firing:

$\square$ Hand-fired
$\square$ Chain grate
$\square$ Pulverized, dry bottom
$\square$ Pulverized, wet bottom
$\square$ Other, specify

$\square$ Underfeed stoker $\square$ Traveling grate $\sqcup$ Spreader stoker $\square$ Cyclones $\square$ Vibrating grates

10. Fly ash reinjection:

$\sqcup$ Yes

$\cup$ No

\section{OIL.FIRED.UNITS}
11. Type of oil:
No. 2
$\square$ No. 6
$\square$ Other, specify
12. Atomization:
$\square$ Oil pressure
$\square$ Steam pressure
$\square$ Compressed air
$\square$ Rotary cup
$\square$ Other, specify
13. Oil preheater:
$\square$ Yes, temp. OF
$\square$ No

Figure 3. Example permit application form for fuel burning equipment 
FUEL DATA

14. Complete the following tables for each type of fuel: *

\begin{tabular}{lc|c|c|c|c|c}
\hline \multirow{2}{*}{$\begin{array}{c}\text { Type of } \\
\text { fuel }\end{array}$} & $\begin{array}{c}\text { Heat content } \\
\text { (BTU/unit) }\end{array}$ & \multicolumn{2}{|c|}{ Percent } & \multicolumn{3}{c}{ Quantity of fuel used } \\
\cline { 4 - 7 } & Ash & Sulfur & Per year & Normal/hr & Maximum/hr \\
\hline Coal & BTU/lh & & & ton & $\mathrm{lh}$ & $\mathrm{lh}$ \\
\hline Oil & BTU/gal & & & gal & gal & gal \\
\hline Gas & BTU/cu ft & & & cu ft & $\mathrm{cu} \mathrm{ft}$ & $\mathrm{cu} \mathrm{ft}$ \\
\hline Wood & BTU/lb & & & ton & $\mathrm{lb}$ & $\mathrm{lb}$ \\
\hline LPG & BTU/gal & & & gal & gal & gal \\
\hline Other & & & & & & \\
\hline
\end{tabular}

\begin{tabular}{l|l|l|l|l}
\hline \multirow{2}{*}{$\begin{array}{c}\text { Type of } \\
\text { fuel }\end{array}$} & \multicolumn{4}{|c}{ Percent annual use } \\
\cline { 2 - 5 } & Winter & Spring & Summer & Fall \\
\hline Coal & & & & \\
\hline Oil & & & & \\
\hline Gas & & & & \\
\hline Wood & & & & \\
\hline LPG & & & & \\
\hline Other & & & & \\
\hline
\end{tabular}

- Obtain fuel analysis from vendor(s) and report on an as-received basis. Use weighted annual averages.

\section{CONTROL EQUIPMENT}

Control equipment code:
(A) Settling chamber
(F) Spray chamber
(B) Cyolone
(C) Multiple cyclone
(D) Electrostatic precipitator
(E) Fabric collector (baghouse)
(C) Cyclonic zcrubber
(H) Packed tower
(I) Venturi
(J) Other

15. Control equipment data:

\begin{tabular}{l|l|l}
\hline \multicolumn{1}{c|}{ Item } & Primary collector & Secondary collector \\
\hline (a) Type (see above code) & & \\
\hline (b) Manufacturer & & \\
\hline (c) Model No. & & \\
\hline (d) Year installed & & \\
\hline (e) Your identification & & \\
\hline (f) Pollutant controlled & & \\
\hline (g) Controlled pollutant emission & & \\
\hline (h) Pressure drop & & \\
\hline (i) Design efficiency & & \\
\hline (j) Operating efficiency & & \\
\hline
\end{tabular}

Figure 3. (cont.) Example permit application form for fuel burning equipment 


\section{EMISSION POINT DATA}

16. Your emission point identification

17. Are other sources vented to this stack?

Yes $\square$ No If yes, identify sources

18. Type: $\square$ Round, top inside diameter dimension

$\square$ Rectangular, top inside dimensions $(L)$

L $\underset{\sim}{\longrightarrow} \times(W)$

19. Height:

Above roof $f$, above ground $\mathrm{ft}$

20. Exit gas:

Temp.

$\circ \mathrm{F}$, Volume acfm, Velocity $\mathrm{ft} / \mathrm{min}$

21. Continuous monitoring equipment: If yes, indicate type Make or model

$\square$ Yes $\square$ No - Manufacturer Pollutant(s) monitored

22. Emission data: Emissions from this source have been determined and such data are included with this appendix:

If yes, check method:

[ Yes

Emission test
№

Emission factor

Figure 3. (cont.) Example permit application form for fuel burning equipment 
Table 9. Information Requirements Associated With Air Quality Permitting Procedures in Selected States

\begin{tabular}{|c|c|c|c|c|c|c|c|c|c|}
\hline \multirow[b]{2}{*}{ State } & \multicolumn{9}{|c|}{ Information Requirement* } \\
\hline & 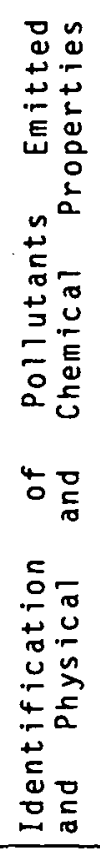 & 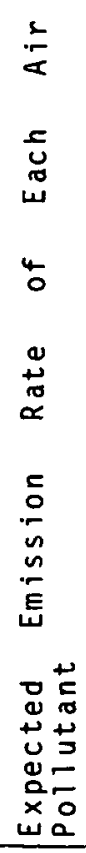 & 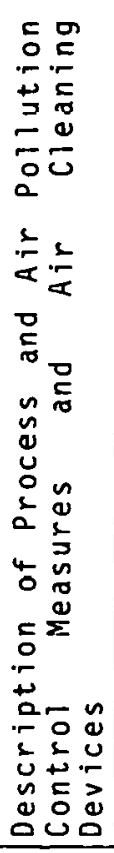 & 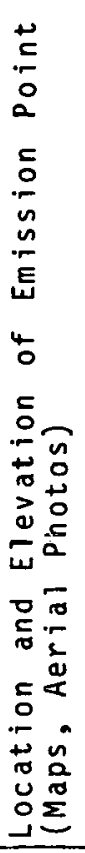 & 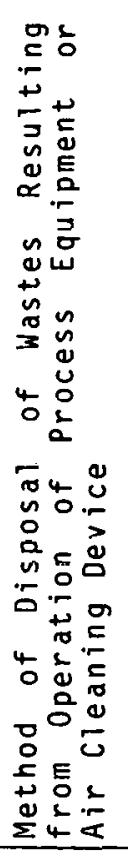 & 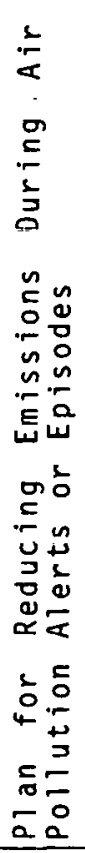 & 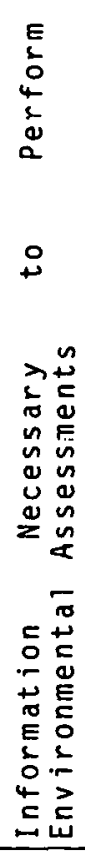 & 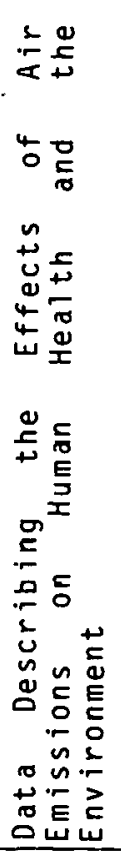 & 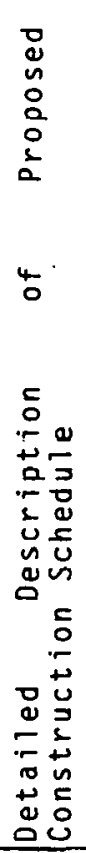 \\
\hline Michigan & $x$ & $x$ & $x$ & $x$ & $x$ & $x$ & $x$ & $x$ & - \\
\hline Missouri & $x$ & $x$ & $x$ & $x$ & $x$ & - & - & $x$ & - \\
\hline Virginia & $x$ & $x$ & $x$ & $x$ & - & - & - & $x$ & - \\
\hline New Mexico & $x$ & $x$ & $x$ & $x$ & - & - & $x$ & $x$ & - \\
\hline Colorado & $x$ & $x$ & $x$ & $x$ & - & - & $=$ & $x$ & - \\
\hline Lake County, Calif. & $x$ & $x$ & $x$ & $x$ & $x$ & - & - & $x$ & - \\
\hline Wyom ing & $x$ & $x$ & $x$ & $x$ & - & - & - & $x$ & $x$ \\
\hline San Diego, Calif. & $x$ & $x$ & $x$ & $x$ & - & - & - & $x$ & - \\
\hline Oregon & $x$ & $x$ & $x$ & $x$ & - & - & - & $x$ & $x$ \\
\hline Al aska & $x$ & $x$ & $x$ & $x$ & - & $x$ & - & $x$ & $x$ \\
\hline
\end{tabular}

*An " $X$ " in the box indicates that the state listed has an information requirement identlcal or 51 milar to that 11 sted In lhe colulirin; a dash indicates that no such requirement was found in the regulations.

Source: State requlations and BNA, 1982. 
obtaining of emission offsets (47 FR 15077). The new facility must still meet applicable emission limits established by NSPS and NESHAP. The rules governing netting in nonattainment areas, which were discussed in Sect. 3.3 .1 of this manual, in the context of calculating significant net increases in emissions from major modifications, are published in $45 \mathrm{FR} 52676$ and $46 \mathrm{FR}$ 50766. The DOE project manager should attempt to use netting wherever possible to reduce the information requirements associated with CAA compliance. To do so, the project manager should be aware of emission thresholds that are applicable to a given project. Close communication between the project manager and the project engineer should facilitate design of emission rates that do not exceed the threshold.

Some DOE projects may be exempt from all or part of the federal offset ruling requirements because of the nature of the project. Fuel conversions are exempt from the requirements of the entire offset policy if the conversion is done by reason of an order under the 1974 Energy Supply and Environmental Coordination Act (ESECA) or by a natural gas curtailment plan, if the source could accommodate the alternative fuel prior to December 21, 1976, or if the conversion uses refuse derived fuel generated from municipal solid waste. Temporary emission sources (e.g., pilot plants), portable facilities that will be relocated away from the nonattainment area after a short time, construction projects, and new resource recovery facilities using municipal solid waste are exempt from obtaining offsets and from demonstrating that a net air quality benefit will occur. Secondary emissions are exempt from the requirement to meet the Lowest Achievable Emission Rate (LAER) and the requirement to demonstrate that all sources in the state are in compliance with all applicable standards and regulations (Fisher and Little 1982).

\subsection{Consideration of Alternatives}

The preparation of an Environmental Impact Statement (EIS) under the National Environmental Policy Act (NEPA) requires the consideration of alternatives. The Clean Air Act also requires the consideration of alternatives for new sources locating in nonattainment areas of ozone and carbon monoxide. Section 172 of the CAA, as modified by the 1977 Amendments, directs, in part (b) (11), nonattainment area poliution control agencies to do the following in nonattainment area plans:

"(a) establish a program which requires, prior to issuance of any permit for construction or modificatoin of a major emitting facility, an analysis of alternative sites, sizes, production processes, and environmental control techniques for such proposed source which demonstrates that benefits of the proposed source significantly outweigh the environmental and social costs imposed as a result of 1ts location, construction, or modification."

These directions apply only to those areas that have received an extension from EPA to meet the ozone and Co standards by December 31, 1982.

Consequently, the manager of a DOE project locating in a nonattainment area for ozone or carbon monoxide that has received an EPA extension can expect to be required to analyze alternatives to the project as required above. An general survey of state regulations found that most states have incorporated this language into their permitting procedures. The DOE project manager should contact the appropriate state or local regulatory agency to determine the level of analysis required for the consideration of al ternatives.

3.9 Post Permitting Requirements

Once DOE has secured a permit to construct and a permit to operate for a given project, it could still be faced with additional information requirements for caA compliance. Three such postpermitting situations in which additional information could be required are in the response to citizen complaints against a facility, annual compliance tests and reinspection, and the renewal of air quality permits. Figure 4 (A) presents basic steps that $D O E$ could be required to complete in order to respond to a community complaint (EPA 1978). In general, responding to citizen complaints primarily entails process adjustments (which could include control equipment installation) to 


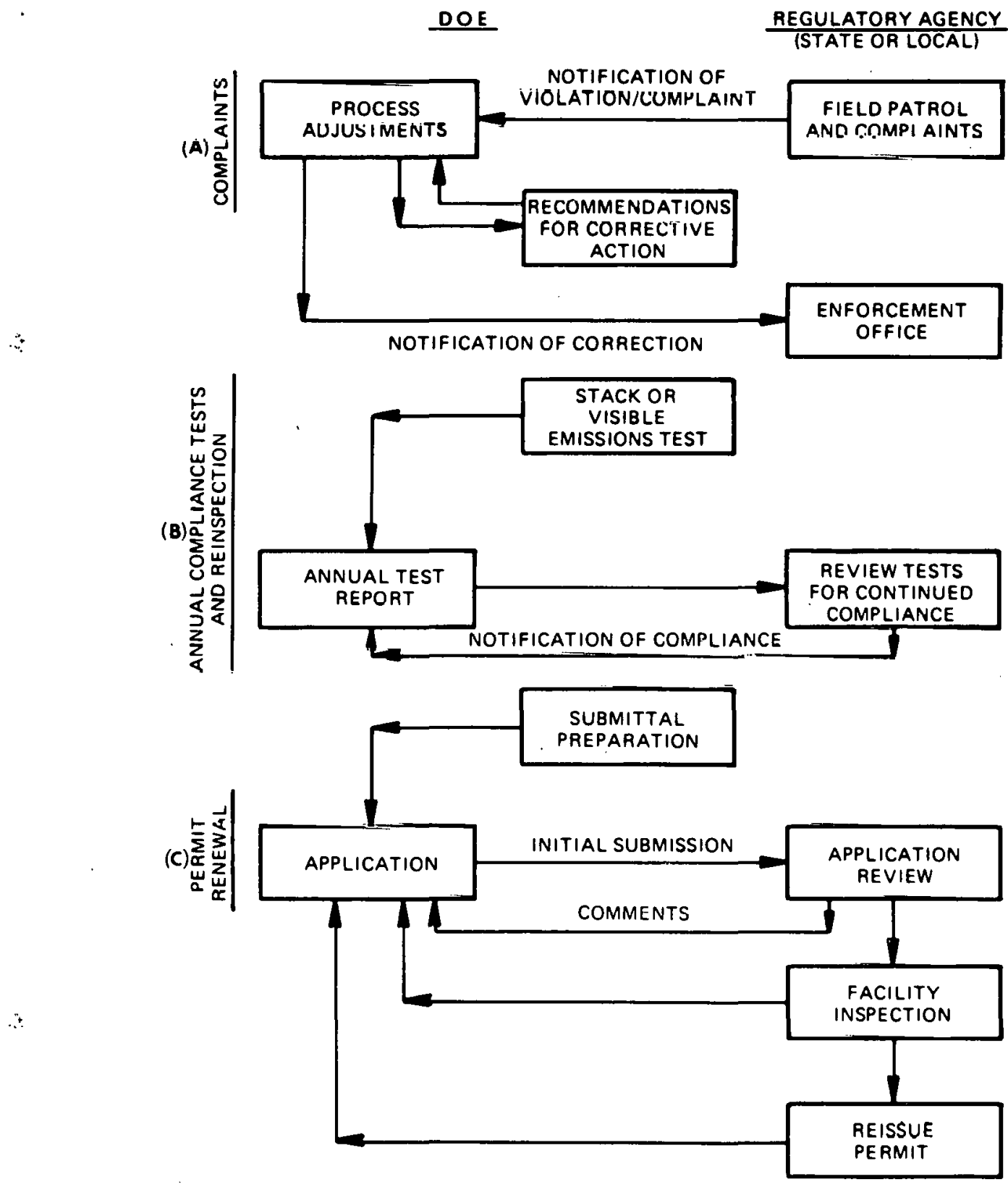

Figure 4. Continuation of Permit System 
reduce emissions below the level contributing to or causing community annoyance. Annual compliance tests [Fig. 4(B)] primarily involve visual or stack tests of emissions from a facility and the preparation of an annual report describing the emission testing. Permit renewal, outlined in Fig. $4(\mathrm{C})$, is basically a reiteration of the permit process, and should involve no new information other than updated changes to processes, physical plant characteristics, and emissions. . In addition to state and local post permitting requirements, DOE facilities must comply with DOE Order 5484.2, which outlines a system for report to DOE Headquarters "unusual occurrences" (e.g., excessive air emissions) that could adversely or potentially affect the "performance, reliability, or safety of a facility" (DOE 1981C).

\section{Summary and Conclusions}

Information requirements for air quality permitting in nonattainment areas are not spelled out in detail in federal laws and regulations, primarily because there are no federal nonattainment area permits issued. Aspects of the federal regulations that potentially require the most information are the determination of Lowest Achievable Emission Rate (LAER), the negotiation of emission offsets, and the consideration of project alternatives in ozone and carbon monoxide nonattainment areas. State regulations developed in response to the federal regulations generally specify in greater detail the information needed to obtain a permit. On the state or local levels, two permits are typically required: one for construction of a facility, and one for the operation of the facility. Applications for permit to construct require emissions data, meteorological and topographical data, and results of air quality dispersion modeling. Permits to operate require compliance with pollutant-specific emission limitations on the state, local, and federal levels; determining compliance with these standards usually requires intermittent testing and sampling, and could in addition require continuous emission monitoring and associated data reporting requirements.

The Clean Air Act is expected to be amended in 1982 or 1983 in connection with periodic reauthorizations of the Act. It is difficult at this time to pinpoint possible changes in the CAA that could affect the permitting process in nonattainment areas. Unless sweeping changes are made to the Act, it is unlikely that any amendments would have a significant effect on nonattainment area permitting because such permitting is done on the local level. If the provisions of the CAA affecting nonattainment area permitting are weakened (made less stringent), states would not be required to change their permitting procedures because any state or local air pollution control regulation can be more stringent than that required by federal law or regulations.

The principal area in which nonattaiment permitting information requirements overlap with information requirements of other regulations is in the providing of emissions data and the use of air quality disperson modeling. These two features of nonattainment area permitting are also required by federal prevention of significant Deterioration (PSD) permitting procedures. In the rare event that ambient air quality monitoring would be required as part of a permit application for a source in a nonattainment area, the PSD monitoring guidelines (EPA 1980c) would probably be used, thus creating another area of information overlap. 


\section{References}

Air Pollution Control Association (APCA). 1982. 1982 Directory, Governmental. Air Pollution Control Agencies. Published by the APCA, Pittsburgh, Pennsylvania.

Bureau of National Affairs, Inc. 1982. Environment Reporter. State Air Laws, Vols 1-3. BNA, Inc., Washington, D.C.

Campbell, W. A., and M. S. Heath, Jr. 1977. Air Pollution Legislation and Regulations. In Air Pollution, Volume V, Third Edition, A. C. Stern, ed. Academic Press, Inc., New York.

Dames and Moore, Inc. 1981. An Investigation of Prevention of Significant Deterioration (PSD) of Air Quality and Emission offset Permitting Processes. Study of PSD and offset Permits. Report to the National Commission on Air Quality, contract No. 1a-AM-7133. As cited in NCAQ, 1981.

Department of Energy (DOE). 1981a: Environmental Compliance Guide, Volume I. US DOE, NEPA Affairs Division, Office of Environmental Compliance and overview, Washington, D.C.

Department of Energy. 1981b. Environmental Protection, Safety, and Health Protection Program for DOE Operations. DOE Order 5480.1A. U.S. Department of Energy, Assistant Secretary, Environmental Protection, Safety, and Emergency Preparedness, Washingt on, D.C.

Department of Energy. 1981c. Unusual Occurrence Reporting System. DOE Order 5484.2. U.S. Department of Energy, Assistant Secretary, Environmental Protection, Safety, and Emergency Preparedness, Washington, D.C.

Department of Energy. 1982. Guidance Manual for Department of Energy Compliance with the Prevention of Significant Deterioration (PSD) Provisions of the Clean Air Act. Oak Ridge National Laboratory, Oak Ridge, Tennessee.

Environmental Protection Agency (EPA). 1980a. Emission Reduction Banking Manual. First Edition. Emission Reduction Banking and Trading Publication No. FG200. U.S. Environmental Protection Agency, Office of Planning and Management, Washington, D.C.

Environmental Protection Agency (EPA). 1980U. Quidelinc on Air Duality Models, U.S. EPA, Office of Air Quality Planning and Standards, Research Triangle Park, North Carolina.

Environmental Research and Technology (ERT). 1980. The Impact of Air Quality Permits Procedures on Industrial Planning and Development. The Business Roundtable Air Quality Project. Volume III. Washington, D.C.

Environmental Protectlon Agency (EPA). 1980c. Ambient Manitoring Guidelines for Prevention of Significant Deterioration (PSD). Report No. EPA-450/4-80-012. U.S. EPA, Office of Air and Waste Management, Office of Air Quality Planning and Standards, Research Triangle Park, North Carolina.

Environmental Protection Agency (EPA). 1980d. Procedures Pui the Preparation of Emission Inventories for Volatile Organic Compounds. Volume $I$. Second Edition. US EPA, Office of AIr, Noise, and Radiation, Office of Air Quality Planning and Standards. Research Triangle Park, North Carolina. EPA-450/2-77-028.

Environmental Protection Agency (EPA).. 1978. Industrial Guide for Alr Pollution Control. Environmental Research Information Center. Washington, D.C. EPA-625/6-78-004.

Faith, W. L. 1977. Agriculture and Agricultural Products Processing. In Air Pollution, 3rd edition, Volume IV, A. C. Stern, ed. Academic Press Inc., New York, pp. $655-685$.

Fisher, P. W. and J. W. Little. 1982. Permitting Under the Clean Air Act. Manual for Air Pollution Control Association Continuing Education Course given in New Orleans, Louisiana, June 19, 1982. 
Liroff, R. A. 1980. Air Pollution offsets. The Conservation Foundation. Washington, D.C.

Mayer, N. 1982. U.S. Environmental Protection Agency. Standards Implementation Branch. Research Triangle Park, NC. Personal communication with D. B. Hunsaker, Jr., Oak Ridge National Laboratory, August 31, 1982.

National Commission on Air Quality (NCAQ). 1981. To Breathe Clean Air. Washington, D.C.

Phillips, J. 1981. Practical Aspects of an Emissions Bank. Proceedings, Economic Incentives for Clean Air. Specialty Conference, Air Pollution Control Association, Pittsburgh, PA.

Prokop, W. H. 1978. "Developing Odor Control Regulations: Guidelines and Considerations". J. Air Poll. Control Assoc. 28 (9-16).

Systems Consultants Inc. (SCI). 1981. Energy and Air Quality. Prepared for U.S. Department of Energy, Assistant Secretary, Environmental Protection, Safety, and Emergency Preparedness, Office of Environmental Programs, Washington, D.C. DOE/EV/10154-3.

Wunderle, J. 1980. Compilation of BACT/LAER Determinations, Revised. U.S. Environmental Protection Agency, Office of Air, Noise, and Radiation, office of Air Quality Planning and Standards. Research Triangle Park, North Carolina. EPA-450/2-80-070. 


\section{Appendix A}

Maps of Areas in the U.S. Recently Designated as Nonattainment

for the Primary National Ambient Air Quality Standards

The geographical information presented in this Appendix allows the DoE project manager to approximate the locations of nonattainment areas in the United States. The project manager should consult 40 CFR 81.300 et seq. and the Federal Register for current and official designations of the attainment status of a particular area.

U.S. Counties Containing Primary $\mathrm{SO}_{2}$ Nonattainment Areas

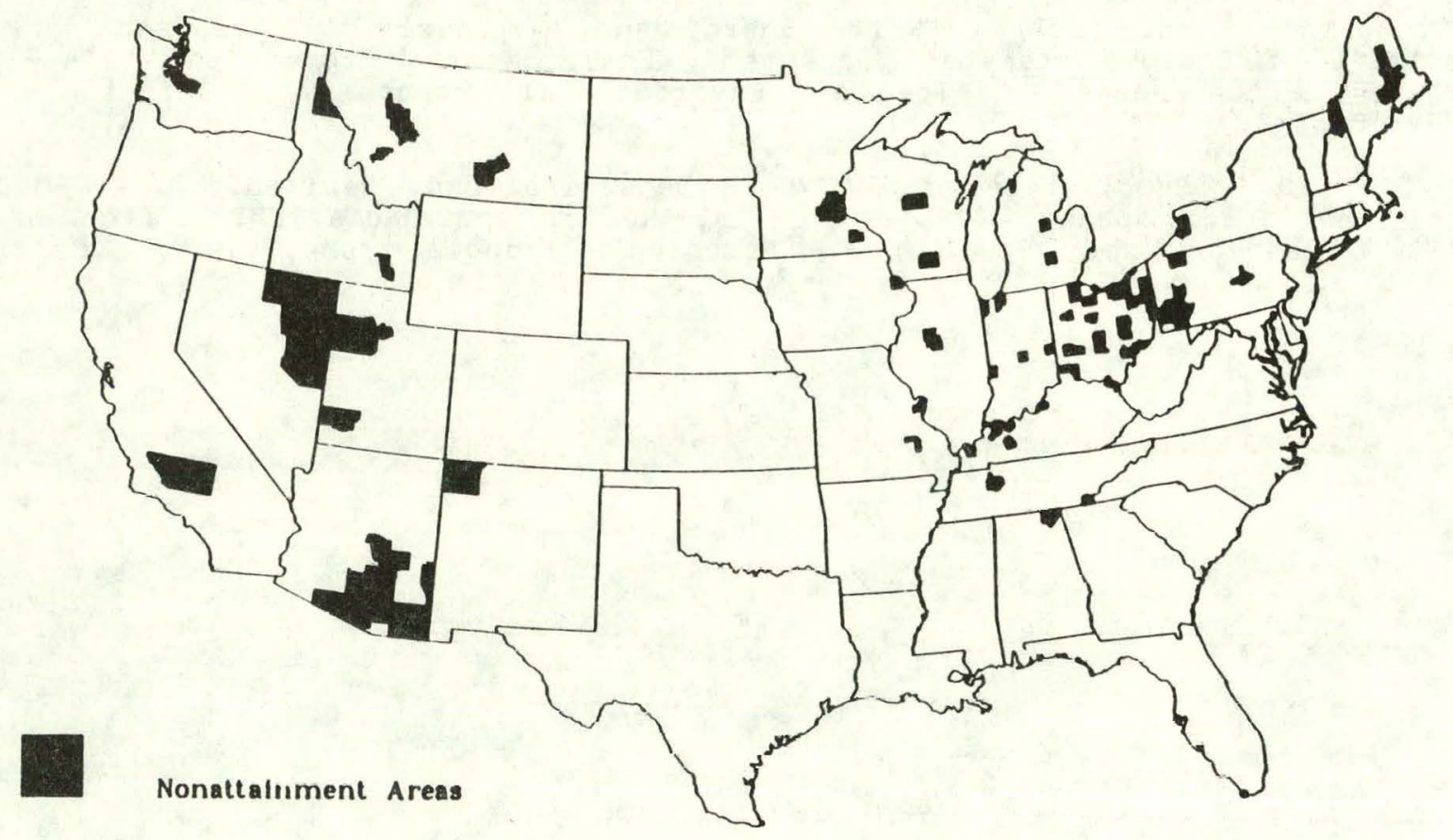

SOURCE: U.S. Department of Energy, Office of Technology Impacts, "In Pursuit of Clean Air: A Data Book of Problems and Strategies at the State Level," ANL/EES-TM-90, Vol. 1, February 1980. As reproduced in SCI 1981. 

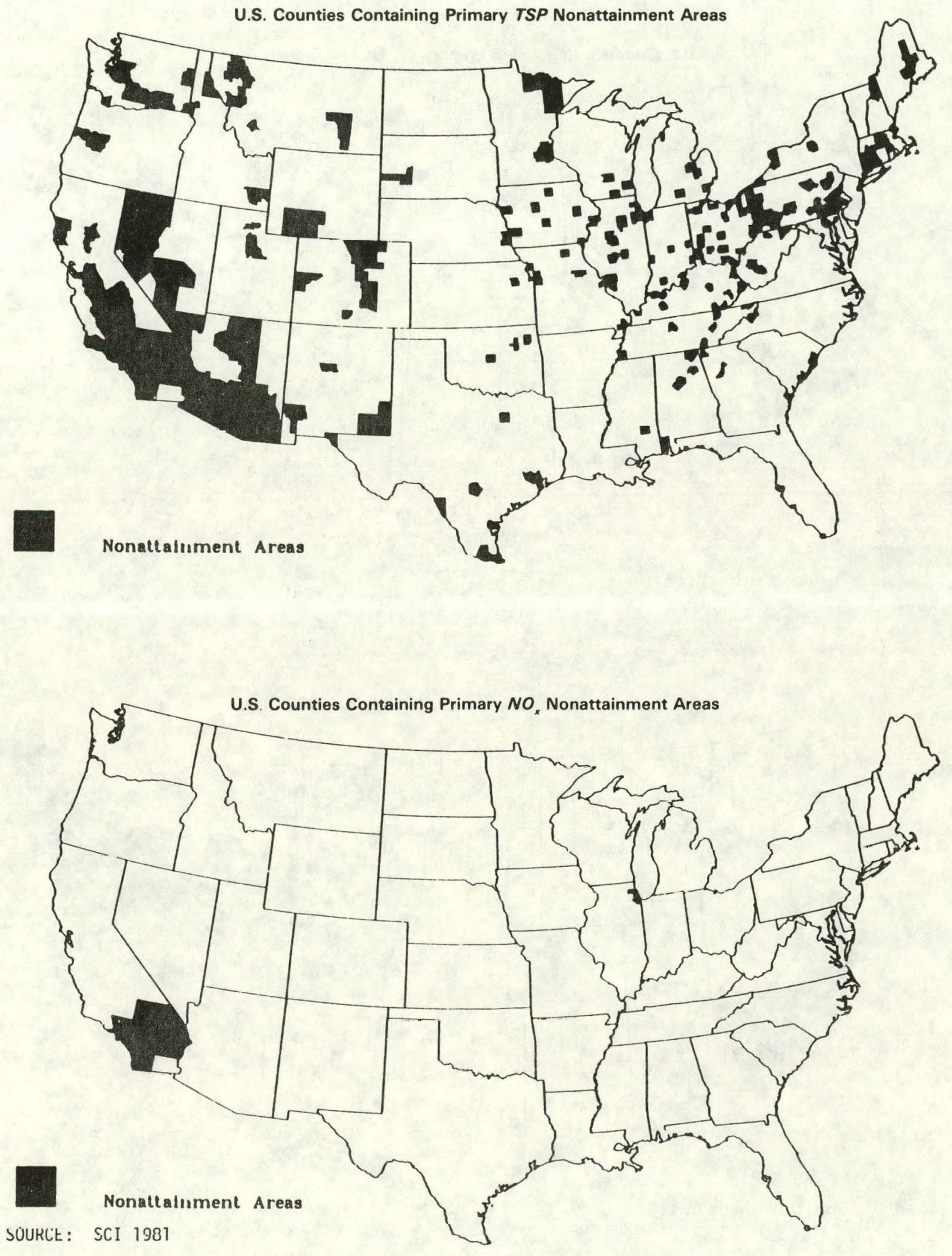

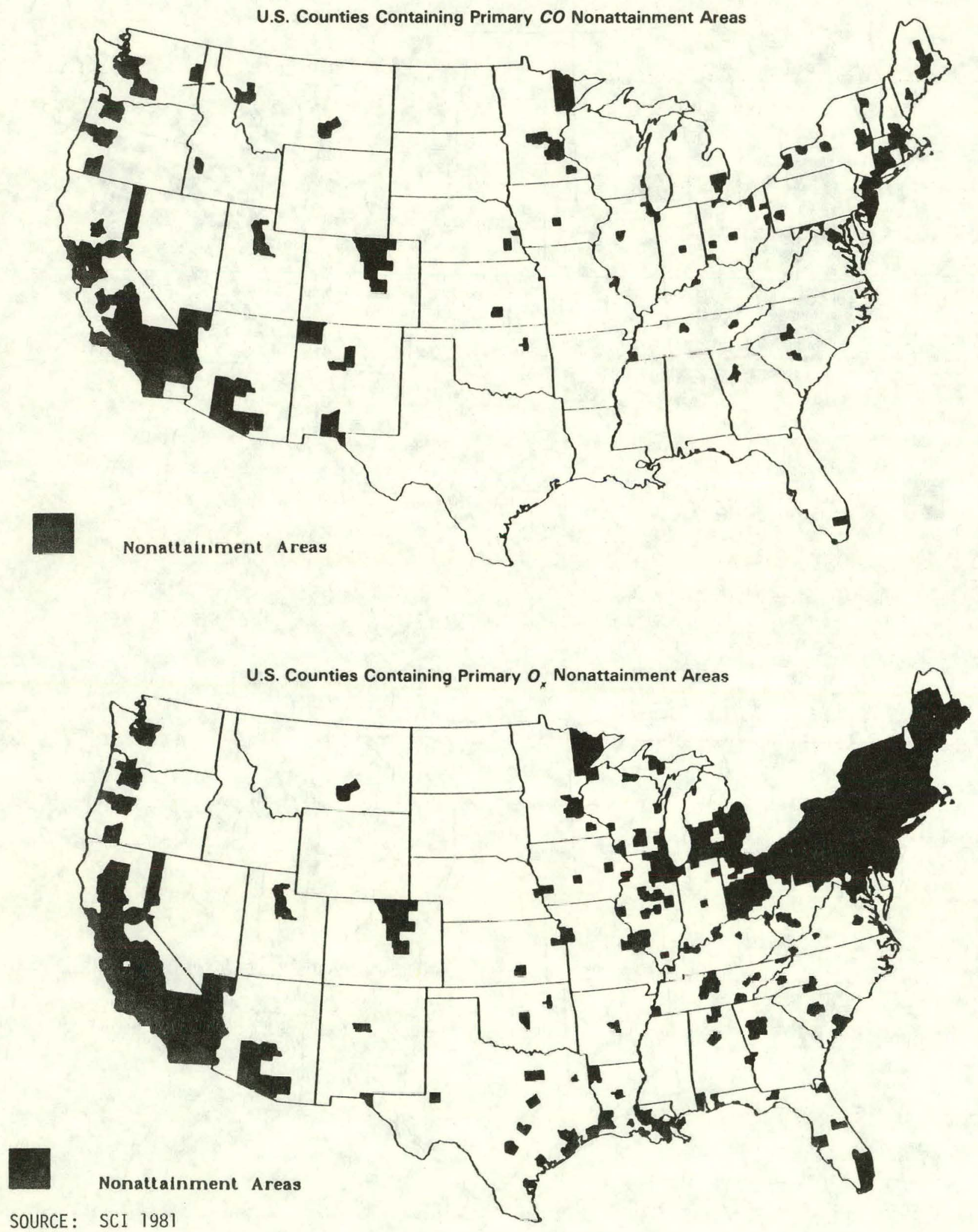
Appendix B

List of States with Authority to Implement New Source Performance Standards*

\begin{tabular}{|c|c|c|c|c|}
\hline Alabama & Kentucky & New Hampshire & & South Dakota \\
\hline Arizona & Maine & New Jersey & . & Tennessee \\
\hline California & Maryland & New York. & & Texas \\
\hline Colorado & Massachusetts & North Carolina & & Utah \\
\hline Connecticut & Michigan & North Dakota & & Vermont \\
\hline Delaware & Minnesota & Ohio & & Virginia \\
\hline Georgia & Mississippi & Oregon & & Washington \\
\hline Idaho & Montana & Pennsy Ivania & & Wiscons in \\
\hline Indiana & Nebraska & Rhode Island & 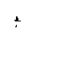 & wyoming \\
\hline I owa & Nevada & South Carolina & & \\
\hline
\end{tabular}

*As of July 1, 1981. Refer to Appendix D for names and addresses, arid telephone numbers of specific state agencies with regulatory authority. Note that the states listed may not have assumed authority to implement all NSPS; in most cases, states elect to implement only portions of the NSPS. 


\section{Appendix C}

List of States with Authority to Implement National Emission Standards for Hazardous Air Pollutants*

\begin{tabular}{lll}
\hline Alabama & Massachusetts & Ohio \\
Arizona & Michigan & Oregon \\
California & Minnesota & Pennsylvania \\
Colorado & Mississippi & Rhode Island \\
Connecticut & Montana & Souț Carolina \\
Delaware & Nevada & Tennessee \\
Georgia & New Hampshire & Texas \\
Indiana & New Jersey & Vermont \\
Kentucky & New York & Virginia \\
Maine & North Carolina & Washington \\
Maryland & North Dakota & Wisconsin \\
\hline
\end{tabular}

*As of July 1, 1981. Refer to Appendix D for names, addresses, and telephone numbers of specific state agencies with regulatory authority. 


\section{State}

Al ab ama

Al aska

Arizona

Arkansas*

Caí ifornia

Colorado

Connecticut

Delaware*

District of Col umbia* District of Columbia Department of

Florida

Georgia

Hawai i *

Idaาo*

III inois Environmental Services, Bureau of Air and Water Quality

\section{Agency Title}

Al abama Air Pollution Control Commission

State of Alaska, Department of

Environmental Conservation

Arizona Department of Health Services

Arkansas Department of Pollution

Control and Ecology

State Air Resources Board

Air Pollution Control Division Colorado Department of Health

Department of Environmental Protection Air Compliance Unit

Delavare Department of Natural

Resources and Environmental Control

Department of Environmental Regulation

Environmental Protection Division Department of Natural Resources

Environmental Protection and Health Services Services Division, Hawai i State Department of Health

Idaho Department of Health and Welfare Division of Environment

Illinois Environmental Protection Agency Division of Air Pollution Control

\section{Agency Address}

645 S. McDonough Street Montgomery, Al abama 36130

Pouch ' 0 '

Juneau, AK 99811

1740 W. Aciams Street

Phoenix, AZ 85007

8001 Naticnal Dr.

Little Rock, AR 72219

1102 Q Street

Sacramenta, CA 95814

4210 E. 11 th Avenue

Denver, CO 80220

165. Capitol Ave., Room $144^{\circ}$

Hartford, CT 06115

P.0. Box 1401

Dover, DE 19901

5010. Overlook Ave., SW.

Washington, DC 20032

Twin Towers Office Building

2600 Blair Stone Rd

Tall ahassee, FL 32301

270 Washington St., SW

Atl anta, GA 30334

1250 Punchbowl Street

Honolulu, HI 96813

450 W. State, 5th Floor

Boise, I0 83720

2200 Churchill Road.

Springfielc, IL 62706
Telephone Number

(205) $834-6570$

(907) $465-2600$

(602) $255-1140$

(501) 371-1701

(916) 322-2895

(303) $320-4180$

(203) 566-4030

(302) $736-4764$

(202) 767-7370

(904) 488-1344

(404) 656-4713

(808) 548-6455

(208) 344-6875

(217) $782-7326$
Contact

James W. Cooper

Ernst W. Mueller

Arthur A. Aymar

Wilson L. Tolefree

James D. Boyd

Earnie E. Vickrey

Leonard Bruckham

Robert R. French

Venkataraman Ramadass

Steve Smal I wood

R. H. Collom, Jr.

Melvin K. Koizumi

Lee W. Stokes

Daniel J. Goodwin

…


Appendix D.

List of State Air Pollution Control Agencies

(continued)

State

Ind i ana

I owa

Kansas

Kentucky

Louisiana*

Maine*

Maryl and

Massachusetts

Michigan

Minnesota

Mississippi*

Missouri

Montana

\section{Agency Title}

Indians State Board of Health

Iowa Department of Envircnmental Qual ity Air and Lard Quality Division

Kansas Department of Health and Environment

Division of Air Pollution Control

Department for Natural Fiesources and Environmental Protection

Department of Natural Resources Office of Environmental Affairs. Air Cual ity Division

Department of Environmen:al Protection Burecu of Iir Qual ity Control

Air Mćnagement Administration Office of Environmental Programs

Divis:on of Air Quality Control

Air Quality Division

Mich gan Department of Natural Resources

Minnesota Pollution Control Agency

Missijsippi Department cf Natural Resoruces Bureau of Pollution Cortrol

Missouri Department of Matural Resources Division of Environmental Quality Air Jollution Control Frogram

Montana State Department of Health and Environmental Sciences, Air Quality Bureau

\section{Agency Address}

$1330 \mathrm{~W}$. Michigan Street Indianapolis, IN 46206

900 East Grand Avenue Henry A. Wallace Building Des Moines, IA 50319

Forbes Field Topeka, KS 66620

Fort Boone Plaza

18 Reilly Road

Frankfort, KY 40601

625 North Fourth Street

Baton Rouge, LA 70804

State House

Augusta, ME 04333

201 W. Preston Street

Baltimore, MD 21201

One winter Street

Boston, MA 02100

P.0. Box 30028

Lansing, MI 48909

1935 W. County Road, B-2

Roseville, MN 55113

2380 Highway 80 West

Jackson, MS 39209

1101 Rear Southwest BoulevarJ Jefferson City, MO 65101

Cogswell Building

Helena, MT 59620
Telephone Number

(317) 633-0600

(515) 281-8853

(913) $862-9360$

(502) 564-3382

(504) 342-1206

(207) 289-2437

(301) 383-2775

(617) $292-5593$

(517) $322-1330$

(612) 296-7301

(601) 961-5171

or 961-5099

(314) 751-4817

(406) 449-3454
Contact

Harry D. Williams

Charles C. Miller

Howard F. Saiger

Norman E. Schell

Gus Von Bodungen

David E. Tudor

George $P$. Ferreri

Kenneth Hagg

Robert P. Miller

J. Michael Valentine

Dwight K. Wylie

Robert J. Schreiber, Jr

Harold W. Robbins 
Appendix D.

List of State Air Pollution Control Agencies

(continued)

State

Agency Title

Nebraska

Nevada

New Hampsh"re*

New Jersey

New Mexico

New York

North Carolina

North Dakota*

Ohia

Ok1 ahoma

Oregon

Pennsylvaniz

Rhode Island
Depertment of Environmental Contro

Division of Environmental Protection

New Hampshire Air Resources Agency

New Jersey Bureau of Air Pallution Control Division of Environmental Qual ity

Departmerst of Environmental Protection

Environmental Improvement Division Health and Environment Department

New York Department of Environmental Conservation, Division of Air

Division of Environmental Management

North Dakota State Department of Health

Ohio Enviranmental Protection Agency

Air Qual ity Service, Environnental Heal th Services, Oklahoma State Department of Health

State of Oregon, Department of Environmental Qual ity

Bureau of Air Quality Control

Rhode Island Division of Air and

Hazardous Materials
Agency Address

301 Centennial Mall South

P.0. Box 94877

Lincoln, NE 68509

201 South Fall Street

Carson City, NV 89710

Hazen Orive

Concord, NH 03301

CN027

Trenton, NJ 08625

P.0. Box 958

Santa Fe, NM 87503

50 Wolf Road

Albany, NY 12223

P.0. Box 27687

Raleigh, NC 27611

1200 Missouri Avenue

Bismarck, ND 58505

361 East Broad Street

Col umbus, $\mathrm{OH} 43215$

1000 Northeast 10th Street

P.0. Box 53551

Okl ahoma City, OK 73152

522 SW Fifth Avenue

Porti and, OR 97204

200 N. Third Street

P.0. Box 2063

Harrisburg, PA 17120

204 Cannon Building

Davis Street

Providence, RI 02908
Telephone Number

(402) 471-2186

Gene Robinson

(702) $885-4670$

(603) 271-4582

(609) 292-5450

(505) 827-5271

(518) $457-7230$

(919) 733-7015

(701) 224-2348

(614) 466-6116

(405) $271-5220$

(503) 229-5696

(717) $787-9702$

(401) 277-2808

Thomas E. Wright

Marshall Rackley

Dana K. Mount

Charles M. Taylor

John W. Gallion

E. Jack Weathersbee

Jame K. Hambright 
Appendix D.

List of Strate Air Pollution Control Agencies (continued)

\section{State}

South Carolina

South Dakota*

Tennessee

Texas

Utah*

Vermont*

Virginia

Washington

West Virginia

Wiscons in

Wyoming*

\section{Agency Title}

South Carolina Department af Health and Environmental Control Bureau of Air Qual ity Control

Department of Water and Natural Resources Office of Ai- Quality and Solid Waste

Tennessee Divison of Air Pollution Control

Texas $A=r$ Control Board

Utah Department of Health

Division of Environment

Bureau of Air Qual ity

\section{Agency Jf Environmental Ccnservation} Air Polluticn Control

State Air Pollution Contral Board

Washington State Department of Energy

West Virginiz Air Pollution Control Commission

Wiscons in Bepartment of Natural Resources Bureau of Air Management

Depar-ment of Environmental Quality
Air Quality Division

\section{Agency Address}

2600 Bull Street

Col umbia, SC 29201

Joe Foss Building

Pierre, SO 57501

TERRA Building

150 Ninth Ave., North

Nashville, TN 32103

6330 Highway 290 East

Aust in, TX 78723

150 W. North Temple

Salt Lake City, UT 84110

State Office Building

Montpelier, VT 05602

Room 803, Winth Street

Office Building

Richmond, VA 23219

M.S., PV-11

01 ymp ia, WA 98504

1558 Washington Street, East

Charleston, WV 25311

Box 7921

Madison, WI 53707

401 W. 19th Street

Cheyenne, WY 82002
Telephone Number

(803) $758-5406$

(605) $773-3329$

(615) 741-3931

or $741-2220$

(512) $451-5711$

(801) 533-6108

(802) 828-3395

(804) $786-2378$

(206) 459-6253

(304) $348-3286$

(608) 266-7718

(307) 777-7391
Contact

W. G. Crosby

Joel C. Smith

Harold E. Hodges

Roger Wall is

Alvin E. Rickers

Richard $A$. Valentinetti
Peter W. Hildebrandt

Carl G. Beard, II

Donald Theiler

Randolph Wood

*Denotes states with no lo:al pcllution control agencies; i.e., the state is the only permit-granting authority. 
Appendix E.

Control Techniques Guidelines Published by

the U.S. Environmental Protection Agency

GROUP I (Issued Prior to January 1978)

Surface Coating of Cans, Coils, Paper, Fabric, Automobiles, and Light Duty Trucks (EPA-450/2-77-008).

Surface coating of Metal Furniture (EPA-450/2-77-032).

Surface Coating of Insulation of Magnetic Wire (EPA-450/2-77-033).

Surface Coating of Large Appliances (EPA-450/2-77-034).

Storage of Petroleum Liquids in Fixed Roof Tanks (EPA-450/2-77-036).

Bulk Gasoline Plants (EPA-450/2-77-035).

Solvent Metal Cleaning (EPA-450/2-77-022).

Use of Cutback Asphalt (EPA-450/2-77-037).

Refinery Vacuum Producing Systems, Wastewater Separators, and Process Unit Turnarounds (EPA-450/2-77-025).

Hydrocarbons from Tank Gasoline Loading Terminals (EPA-450/2-77-026).

Design Criteria for Stage I Vapor Control Systems, Gasoline Service Stations, U.S. EPA, OAQPS, November 1975. Unpublished.

GROUP II (Issued in 1978)

Leaks from Petroleum Refinery Equipment (EPA-450/2-78-036):

Surface Coating of Miscellaneous Metal Parts and Products (EPA-450/2-78-015).

Manufacture of Vegetable Oil (EPA-450/2-78-035).

Surface Coating of Flat wood Paneling (EPA-450/2-78-032).

Manufacture of Synthesized Pharmaceutical Products (EPA-450/2-78-029).

Manufacture of Pneumatic Rubber Tires (EPA-450/2-78-030).

Graphic Arts - Rotogravure and Flexography (EPA-450/2-78-033).

Petroleum Liquid Storage in External Floating Roof Tanks (EPA-450/2-78-047).

Perchloroethylene Dry. Cleaning Systems (EPA-450/2-78-050).

Leaks from Gasnline Tank. Trucks and Vapor Cullection Systems (ËPA-450/2-78-051).

GROUP III (None yet published in final form)

Volatile Organic Liquid Loading into Railcars.

Volatile Organic Liquid Storage.

Petroleum Solvenl ory cleaning. ${ }^{a}$

Fugitive voC, Natural Gas and Natural Gasoline Processing Plant.s. ${ }^{a}$

rolymers and Resins Manufacturing.

Fugitive voc, Synthetic Organic Chemical Manufacturing Industry (SOCMI). ${ }^{a}$

Air Oxidation, Synthetic Organic Chemical Manufacturing Industry (SOCMI).

aDraft versions currently under review.

SOURCE: EPA 1980d. 


\section{UNITED STATES}

DEPARTMENT OF ENERGY

WASHINGTON, D.C. 20585

OFFICIAL BUSINESS

PENALTY FOR PRIVATE USE, $\$ 300$
POSTAGE AND FEES PAID U.S. DEPARTMENT OF ENERGY

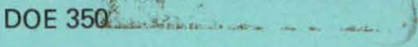

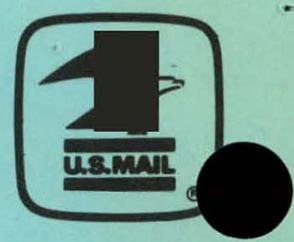

THIRD CLASS MAIL 